\title{
Placing World War I in the History of Mathematics
}

\author{
David Aubin and Catherine Goldstein
}

\begin{abstract}
In the historical literature, opposite conclusions were drawn about the impact of the First World War on mathematics. In this chapter, the case is made that the war was an important event for the history of mathematics. We show that although mathematicians' experience of the war was extremely varied, its impact was decisive on the life of a great number of them. We present an overview of some uses of mathematics in war and of the development of mathematics during the war. We conclude by arguing that the war also was a crucial factor in the institutional modernization of mathematics.
\end{abstract}

Les vrais adversaires, dans la guerre d'aujourd'hui, ce sont les professeurs de mathématiques à leur table, les physiciens et les chimistes dans leur laboratoire. Guerre à distance, guerre d'industrie.

— Jeanne Alexandre, 6 February, 1916 [Weis 2005, p. 83].

"Our true adversaries in today's war are mathematics professors at their tables, physicists and chemists in their laboratories. War at a distance, war of industry." Jeanne Alexandre was the sister of the sociologist Maurice Halbwachs who took part at cabinet level in the early mobilization of French industry for war. By 1916, she had become a staunch pacifist. To her eyes, the mathematician, and more generally the scientist, stood as the very symbol of what she hated the most about the Great War, the inhuman, destructive nature of fighting at a distance, as well as the tragic alliance of science, industry, and warfare.

Two years later, on the Italian front, British Private Edgar Norman Gladden concurred with Alexandre in attributing a special place to mathematics in this war. At barely twenty-one, he was already a veteran of the Somme and Ypres when in June 1918 he was ordered to take a small ridge previously held by German-Austrian troops. Reaching a point brutally shelled for several days, he commented:

The crater, which I expected to see as an immense jagged hole in the ground, was actually a large flat-bottomed depression like a frying-pan, clear and clean from debris except at the further edge, where vestiges of one of the enemy's trenches showed through its side. The poor devils caught in that terrible cataclysm had no chance.

"Yet what chance was there," Private Gladden went on, "for anyone in that war of guns and mathematics?" [Gladden 1930, p. 121]. 
While heavy artillery posed a set of problems about the location of targets and the computation of trajectories for which mathematical expert knowledge proved crucial, countless technological and military innovations which came to light during WWI also relied on precise mathematical analyses. Keeping an aiplane in the air or bringing it down imposed to solve several mathematical problems. ${ }^{1}$ The development and improvement of technologies such as the sonar or wireless telegraphy, as well as the application of cartography or meteorology to a daily military usage, required mathematical skills that were perhaps less innovative, but nevertheless rare among the draftees. Soon, mused a reporter tongue-in-cheek, "armies will be commanded by mathematicians whose essential function, in times of war, will precisely be to busy themselves with mathematics" [D 1915, p. 9]? While this prediction was never realized, the French mathematician Paul Painlevé, an aeronautics specialist, indeed was, over the course of the war, minister of inventions, minister of war and, briefly, head of State from September to November 1917. It was in this capacity that he had selected Marshall Ferdinand Foch to become Chief of the General Staff. On 11 November, 1918, Foch was admitted to the Academy of Sciences and Painlevé used a string of mathematical metaphors to praise Foch's "logical power." Foch's final assault against the Germans was compared to "a sequence of theorems" and evoked to Painlevé "the old Platonic axiom: 'Divine things are accomplished by geometry'." ${ }^{2}$

Rhetorics aside, the realization that war and mathematics had become entangled was by no means restricted to Allied nations. The first volume in a series of "German booklets for the front and the nation" published by Teubner in Leipzig dealt with Mathematics in War (figure 1). In this booklet of which a thousand copies were sent free of charge to the front, Dr. Paul Riebesell, a highschool teacher in Hamburg, explained:

Without mathematics, physics would not be in position to state countless laws, it would not be possible for technology to compute and planned its devices. Thus can this war, which has often been called technological, also rightly be called a mathematical war [Riebesell 1916, p. 1].

From high command to the infanterymen, soldiers depended on mathematics often without being aware of it. But make no mistake, Riebesell claimed: "wherever you look in battle, mathematics rules" [Riebesell 1916, p. 2]. Focusing on ballistics and orienteering, this booklet offered a convincing demonstration of the value of basic mathematical thinking in modern warfare.

To speak of the First World War as a "scientific war" [Wells 1915] has become common. But the conflict is mostly associated with chemistry, aerodynamics, mechanical engineering rather than mathematics. The truth is that adhesion to war aims was so widespread among contemporaries that almost every corner of the scientific, and indeed cultural, landscape was engulfed by what became known as a "total war" [Daudet 1918]. Examples just mentionned bring to fore the feeling that mathematics and mathematicians also were considered as major players in

\footnotetext{
${ }^{1}$ This is recalled by June Barrow-Green in her contribution to this volume.

${ }^{2}$ See Comptes rendus hebdomadaires des séances de l'Académie des sciences [hereafter $C R A S] 167$ (1918), p. 718. On Painlevé's role during WWI, see [Fontanon \& Franck 2005, Anizan 2006].
} 


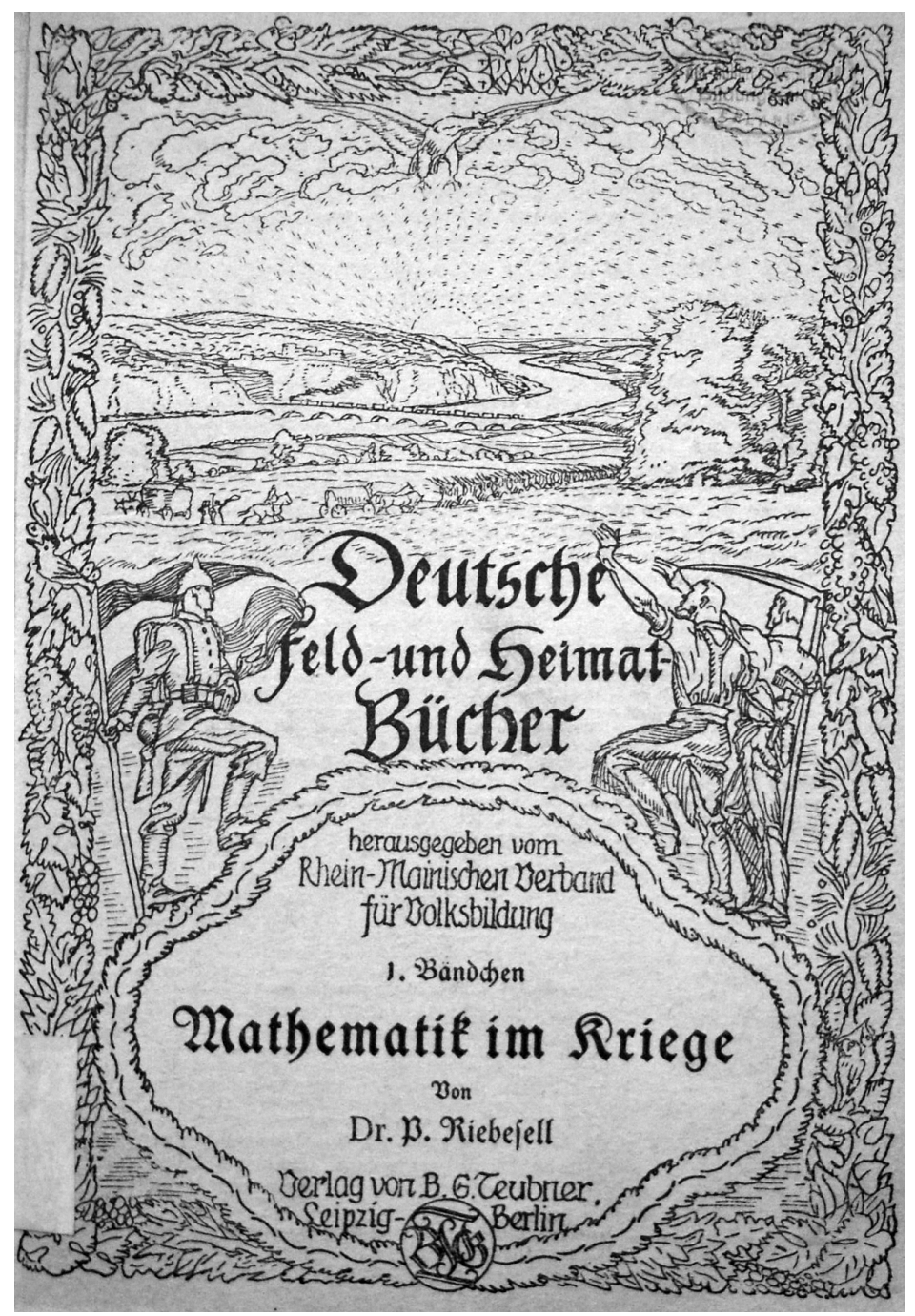

Figure 1. "Mathematics in War", cover [Riebesell 1916].

what George Greenhill had also, and before Riebesell, described as a "mathematical war." ${ }^{3}$ Still, the historian of mathematics is confronted with some paradoxes.

First, whereas the production of war materials and their use in the field was widely perceived as requiring a certain degree of mathematical aptitude, it was much less obvious whether mathematicians could or should have a special role in the war. The mathematicians' own experience seemed sometimes at discrepance with the public perception. Eager to contribute to the war effort in the spring of 1917, Oswald Veblen expressed the difficulty he had to put his skills in manipulating abstract notions at the service of his belligerent nation. As late as 19 May, 1917, the young mathematician from Princeton University still confided to George David Birkhoff: "Thus far I have failed to find any place in which mathematical work is

\footnotetext{
${ }^{3}$ See Barrow-Green's contribution to this volume.
} 
of use in connection with the war. If you run across anything of the sort I wish you would let me know." 4

A second paradox arises from the way in which mathematicians' collective organization shaped their personal responses to their war experiences. By then, mathematicians had in most countries acquired a sense of community. National societies had been established in the later part of the nineteenth century and a professional identity structured around definite research agendas and educational missions had emerged. National differences were of course discussed and underscored: looking for the best experts to synthesize every field of the mathematical sciences in his Encyklopädie der mathematischen Wissenschaften, Felix Klein specifically sought out Italian writers for chapters on algebraic geometry and British ones for mechanics. The mathematical chronicler the Revue du mois (Émile Borel most probably) wrote that "there was no reason to regret the fact the young French mathematical school leaves aside these number-theoretical studies favored in Germany" [Anonymous 1906, p. 510]. On the basis of a strong national structuration of their communities, mathematicians had however started to reinvent the internationalism of their trade. Some mathematicians among the most prominent emphasized the universality of mathematics. Academic voyages had become frequent, at least in Europe; national societies and academies admitted foreign members; several journals attracted an international pool of writers; and International Congresses of Mathematicians had taken place roughly every four years since 1897, in Zurich, Paris, Heidelberg, Rome, and Cambridge. In the prewar years, an International Commission for Mathematical Instruction (ICMI) was especially active in promoting and reforming the teaching of mathematics at all levels of the school and university curricula. ${ }^{5}$

To assess the effect of war on these men and communities therefore is no simple task. When knowledge, as it is the case for mathematics, appears as highly abstract and remote from mundane reality, even an event as dramatic in its social and political effects as World War I can vannish from sight. For some contemporaries, to "cry for patriotic mathematics" seemed like an all-too-obvious contradiction in terms [Bell 1915, p. 6]. Because of this perception, the First World War had by and large been neglected from the written history of twentieth-century mathematics. In an article about the history of mathematical logic, just to take one example, the period 1915-1930 appears under the heading "The Optimistic Times" [Guillaume 1994, p. 214]. Yet, nearly all mathematicians discussed in the volume from which this article is taken [Pier 1994] had been through life-changing experiences: some had lost sons and students; some had been severely wounded in bloody battles; many had spent several year burried in the mud of the trenches; other had been called to contribute to the war effort in various capacities as truck drivers, translators, computers, mathematical instructors, scientific advisors to general staffs and governments, or members of these governments (figure 2).

More inclined to pay attention to the social and institutional context in which science was pursued, some historians of science have clearly identified the Great War

\footnotetext{
${ }^{4}$ [Birkhoff Papers, HUG 4213.2, Box 3]. For some discussion of the war context in Birkhoff's work, see [Aubin 2005]. The American mathematicians' mobilization is discussed in Thomas Archibald, Della Fenster, and Deborah Kent's contribution to this volume.

${ }^{5}$ On these issues the literature is now vast; for international overviews, see [Mehrtens 1990, Goldstein et al. 1996, Lehto 1998, Parshall \& Rice 2002, Coray et al. 2003].
} 


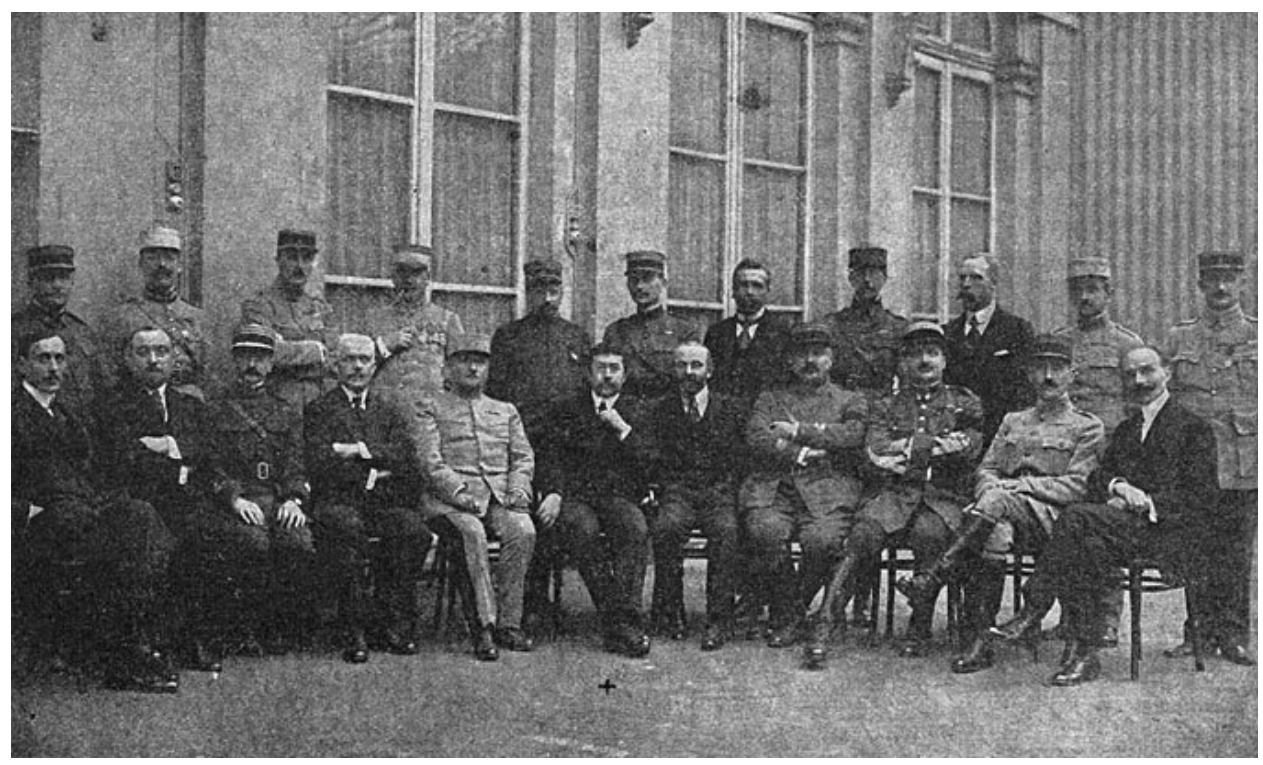

Figure 2. Paul Painlevé's Cabinet as Minister of War, 1917

as a key episode in the development of powerful scientific communities. ${ }^{6}$ With the hindsight of World War II and of the Cold War, and in a context of countercultural denunciations of the role of the military in the sciences, these historians documented the ways in which various forms of scientific mobilization, hastily put together between 1914 and 1918, formed the matrix for a future, deeper reorganization and growth of a scientific complex that was to be placed at the service of the State and of the military. Further studies along those lines have been useful in underscoring the privileged position scientists then carved for themselves as the primary interlocutors of general staffs for all matters regarding inventions and technological innovations. ${ }^{7}$ WWI thus appeared as both the root and the imperfect prefiguration of forms of big science to become dominant only in the 1940s and 1950s.

From this historiography, mathematics was generally absent, although mathematicians appeared here and there sometimes playing decisive roles as science diplomats [Schroeder-Gudehus 1978, Dauben 1980]. Only in the 1990s did historians of mathematics start to pay attention to WWI in their studies. In his history of the International Mathematical Union (IMU), Olli Lehto argued for instance that WWI was instrumental in making politics enter international cooperation in science[Lehto 1998].

In emphasizing institutional innovations, historians were echoing assessments widespread among contemporary scientists who saw in the Great War a series of "lessons" to be drawn for future mobilizations, but without much impact on the

\footnotetext{
${ }^{6}$ See, e.g., [Kevles 1995, first published in 1978 but announced by several papers published separately]; see also [Forman 1974, MacLeod \& Andrews 1971, Hughes 1977, Weart 1979, Varcoe 1970]. For a review of this type of work, see [Hartcup 1988].

${ }^{7}$ From a vast literature, let us cite [Pattison 1983, Roussel 1989, Johnson 1990, Hull 1991, Lepick 1998, Aubin \& Bret 2003, MacLeod \& Johnson 2006, Galvez-Behar 2008].
} 
content of science. The American physicist George K. Burgess was typical in writing in 1919 that, while hundreds if not thousands of new applications of known principles were due to war work, one would be hard pressed to name even two or three new principles developed due to the war [Burgess 1919, p. 98]. Historians of mathematics tended to agree:

The disciplinary center of mathematics remains autonomous and "pure", untainted by ends to which it would just be a means. [...] At the same time, however, the web of practices and specialties connecting it to the military [...] was made more dense and more stable [Mehrtens 1996a, p. 95].

Disloged from their usual workplaces and puzzling over problems far afield from their previous occupations, mathematicians often felt that the war had been nothing but a parenthesis as far as normal science was concerned. Yet, contemporaries were divided about the lessons one was to draw from the experiences of WWI [Forman 1973]. While some scientists bracketed their war experience - "the war of course was a big hole," later said the applied mathematician Richard Courant [AIP 1962] - others considered that this was the dawn of a new age, the "scientific and industrial age" [Moureu 1920, p. 376], or a "New World of Science," as an American book proclaimed in its title [Yerkes 1920]. Many of those who had taken part in the formidable technoscientific or industrial mobilization (scientists, engineers, inventors, industrialists, or military personnel) marvelled at the number of great realizations made possible during the war. The war confirmed the scientific nature of the modern world, and the need to infuse its values and techniques throughout society. Both views were not mutually exclusive: as is recalled in the contribution on Paris mathematicians by David Aubin, Hélène Gispert, and Catherine Goldstein below, Borel who played major roles in war mobilization and postwar reorganization of science in France, wrote in support of his candidacy to the Academy of Sciences after WWI that, having published no new mathematical paper, he had nothing to add to the report he had written in 1914 [Gispert \& Leloup 2009, p. 47-48]. War then can be both a break in what one considered to be one's properly scientific activity and, at the same time, a means allowing the emergence of new social structures for science policy. An autoritative history of mathematics in the U.S. thus argued that war was a "furlough" away from pure research for most American mathematicians after which they, by and large, had "little inclination" to pursue applications [Parshall \& Rowe 1994, p. 444].

Agreeing with the view that the relation between mathematics and the military was necessarily "mediated" by technology and engineering [Mehrtens 1996a, p. 87], a ground-breaking survey of war-related mathematics has attempted to list the "social and epistemic environment for applications of mathematics" in various countries [Siegmund-Schultze 2004]. Emphasizing the need for a long-term history of industrial mathematics, Siegmund-Schultze underscored "the short distance between basic academic research and applied work for the military" and focused on the mathematics explicitely used by the military (mostly during WWII). His study however gives very little clues about larger-scale changes in mathematics that could be ascribed to the war after WWI. Traumas and ruptures caused by WWI are thus restricted, in the literature, to mathematicians' personal lives and to the institutional settings for mathematics. War seemed to leave little imprint, if at all, on the development of mathematics either as discipline or as body of knowledge. 


\section{Two Theses about the Effect of War on Mathematical Knowledge}

There are however two historiographical theses that actually argue that the First World War had a major effect on mathematical knowledge. The "Forman thesis" famously suggested that German mathematicians and physicists accomodated to the irrational mood of Weimar culture and gave up causality and determinism as major demands for scientific explanations, thereby paving the way for the spectacular development of quantum mechanics [Forman 1971]. Although this is not an aspect that is usually put forward, the Forman thesis thesis can be read, as we shall see, as arguing that WWI was instrumental in ushering modern theoretical physics and mathematics. The second thesis - the "Bourbaki thesis," as we shall dub it - was formulated a few years before Forman's not by historians of science but by mathematicians looking back at their own past. It has since been widely taken up and become a standard trope in the historiography. ${ }^{8}$ In this thesis, contrary to Forman's, the ascendency of what was perceived as antimodern trends in postwar French mathematics is also seen as a direct consequence of war.

1.1. The Bourbaki Thesis. The first promoters of the Bourbaki thesis are to be found among the founders of the group set up in 1934-1935 in order to introduce modern elements inspired by David Hilbert's Göttingen school into the French university curriculum. ${ }^{9}$ Put briefly, the Bourbakis claimed that the bloodbath of the Great War essentially wiped out an emerging generation of mathematicians in France, later leaving those who were trained in the interwar period alone in front of professors who held outdated views about their discipline. In 1969, Jean Dieudonné explained:

In the great conflict of 1914-18 the German and French governments did not see things in the same way where science was concerned. The Germans put their scholars to scientific work, to raise the potential of the army by their discoveries and by the improvement of inventions or processes, which in turn served to augment German fighting power. The French, at least at the beginning of the war and for a year or two, felt that everybody should go to the front; so the young scientists, like the rest of the French, did their duty at the front line. This showed a spirit of democracy and patriotism that we can only respect, but the result was a dreadful hecatomb of young French scientists. When we open the war-time directory of the École Normale, we find enormous gaps which signify that two-thirds of the ranks were mowed down by the war. This situation had unfortunate repercussions for French mathematics [Dieudonné 1970, p. 134-135, our emphasis].

Twenty five years later, André Weil who had also partaken in the foundation of Bourbaki concurred in those terms:

Already when I was at the School [the École normale supérieure, hereafter ENS], I had been deeply struck by the damage wreaked upon mathematics in France by the 1914-18 war. This war had

\footnotetext{
${ }^{8}$ See [Andler 1994], [Houzel 2004, p. 56], [Berger 2005, p. 151], [Audin 2009, p. 22-27], [Audin 2010, p. 1300].

${ }^{9}$ The Bourbaki literature is growing fast: see, among others, [Beaulieu 1993, Beaulieu 1994, Aubin 1997, Houzel 2004, Mashaal 2006].
} 


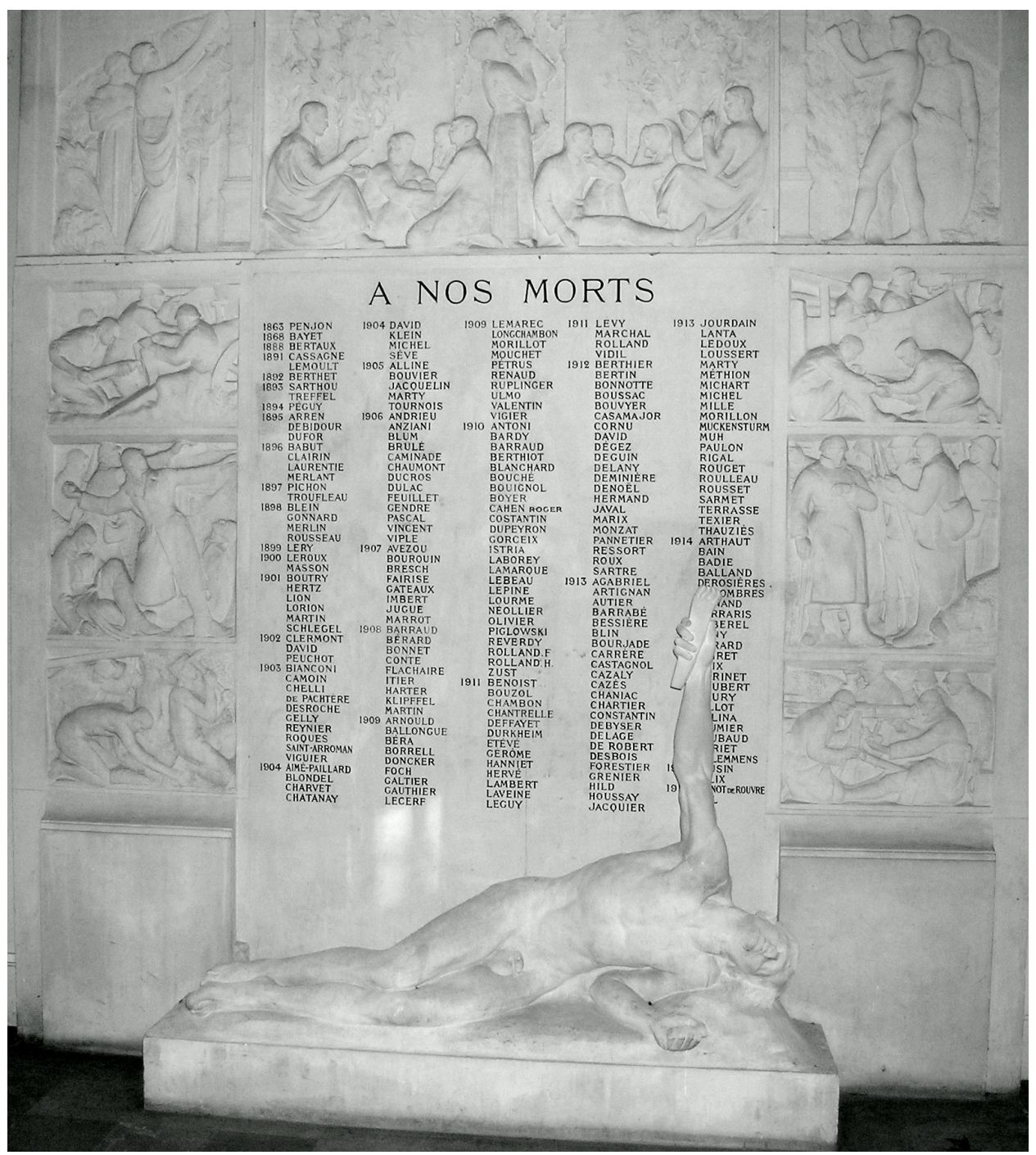

Figure 3. "To Our Dead." Paul Landowski, War Memorial to the Alumni of the École normale supérieure, Paris, 1923. For more about the memorial, see [Hottin 2000]. Photo by David Aubin.

created a vacuum that my own and subsequent generations were hard pressed to fill. In 1914, the Germans had wisely sought to spare the cream of their young scientific elite and, to a large extent, these people had been sheltered. In France, a misguided notion of equality in the face of sacrifice - no doubt praiseworthy in intenthad led to the opposite policy, whose disastrous consequences can be read, for example, on the monument to the dead of the École normale [Weil 1991, p. 132] (see fig. 3). 


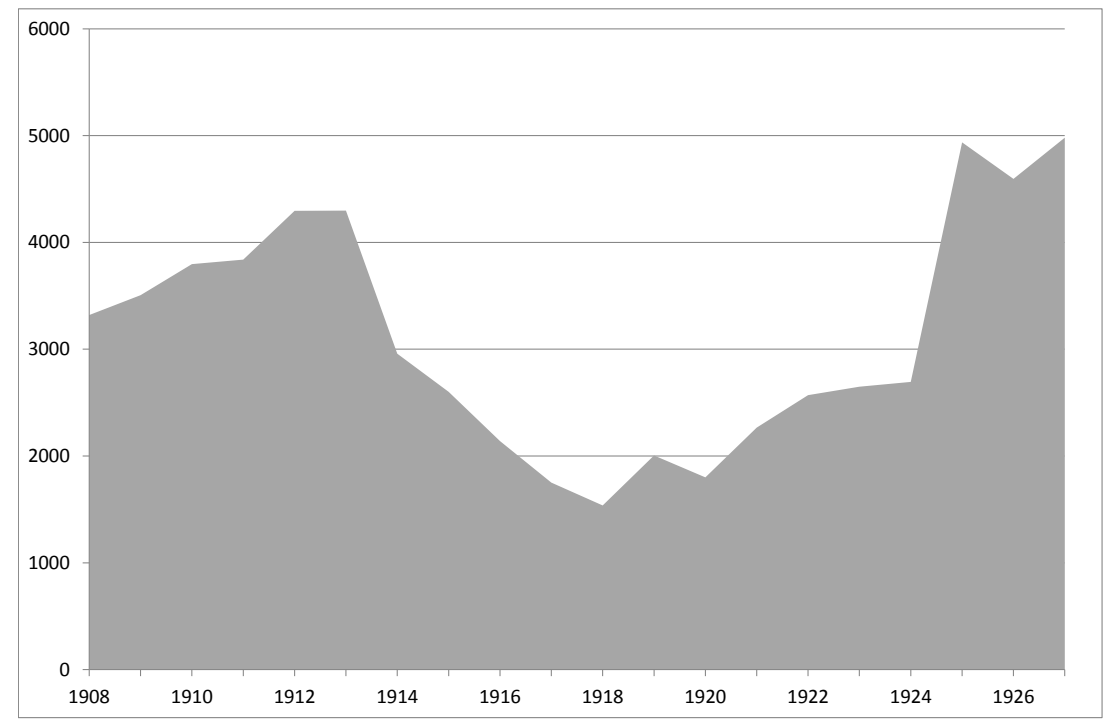

Figure 4. Total number of items reviewed in the Jahrbuch des Forschritte der Mathematik by year of publication, 1908-1927.

In France, almost all of those who were able to pursue a professional research career in mathematics before the war had studied at the ENS [Gispert 1991]. The dreadful rate of casualty among its students was naturally interpreted as especially tragic for the future of learning. From the class entering in 1910, more than 6 out of 10 science graduates never came back from the front. Fatal casualties in the following two cohorts were also above fifty percent of total enrollment in the science section. In speeches made in January 1915, ENS officials noted that out of the 195 mobilized students, at least 34 were confirmed dead, 15 had disappeared, 21 were taken prisoners, 64 wounded: only 54 or 55 remained unharmed! ${ }^{10}$ It was against this terrible backdrop that the Bourbaki thesis emerged.

That war was a tremendous disruption for mathematical research is obvious. To make this apparent, let us consider how the worlwide mathematical production drastically went down in those years. Figure 4 shows a clear and marked drop in the number of items reviewed in the Jahrbuch der Forschritte der Mathematik already in 1914, down by $31 \%$ ccompared to the prewar peak in 1913, when close to 4,300 papers and books were reviewed. The reviewing activity stayed below the level of 1913 until 1925 reaching a low point in 1918 when the number of items reviewed barely reached $36 \%$ of the prewar value. Assuming a constant progression

\footnotetext{
${ }^{10}$ These numbers are recalled and further discussed in the contribution on Paris mathematicians by Aubin, Gispert, and Goldstein in this volume. For a comparative study of casualty at the ENS in WWI, see [Aubin, in preparation].
} 
in the number of items between 1913 and 1925, we could say that more than 25,000 articles or books are, in some sense, "missing." 11

Quantitative comparisons cannot recapture the contrast felt by young mathematicians between what they saw as the dynamic modernity of Göttingen and the depressing atmosphere of postwar mathematical Paris. Future members of Bourbaki indeed overlapped almost exactly with the students who had the opportunity to travel to Göttingen at the end of the 1920s - often sent with the Rockefeller foundation's support by the very members of the older generation that was nearly nonexistant according to the Bourbaki thesis [Siegmund-Schultze 2001]. But when they sought to explain their impression by the conviction that the slaughter was proportionally greater on the Western side of the trenches, Dieudonné and Weil produced an account whose plausibility will be undermined by much of what is found in this book. ${ }^{12}$ They no doubt encountered a community where the memories of WWI took on a wholly different shape than at the ENS, but were they right to assume that German mathematicians were better protected than their French counterparts? As noticed above, differences between researches pursued in France and Germany preexisted the war: the real issue is how the war and the postwar reconstruction changed or not these research trends. Dieudonné's acknowledgement in 1988 that he had completely ignored the work of topologist Louis Antoine - a veteran of the First World War - even though they both taught at the university of Rennes from 1933 to 1937, is a telling example of the divergence in mathematical interests that seemed to occur between the war generation and the Bourbaki mathematicians. "Retrospectively, I regret not having exchanged with Antoine mathematical ideas which might have been useful to us both; but the obstacle to this exchange was my deep ignorance, at this time, of the topics he had dealt with in his work" [Dugac 1995, p. 11].

Retaining a single aspect of the war period - the tragic loss of a significant number of mathematicians - the Bourbaki thesis has therefore hampered a serious consideration of wartime events and experiences as crucial elements for shaping postwar mathematical cultures. War, as it was lived by mathematicians on the front or in the rear, was put at a distance. To better assess the outlines of the mathematical values held by postwar practioners, we claim that it may be necessary to reconsider unresolved issues. How was WWI a disruption, if at all, in the mathematical activities of its contemporaries? How did the surviving mathematicians, in France, but also elsewhere else, reconnect - if they ever did - with their prewar activities? Did mathematicians who change occupations due to the war consider the conflict as a mere interlude in their professional lives or as a fundamental break?

1.2. The Forman Thesis and the Bracketing of WWI. We believe it is enlightening to consider the way in which the Forman thesis has drawn attention to major postwar disruptions in theoretical physics and mathematics in the context of

\footnotetext{
${ }^{11}$ About the history of mathematical reviewing and the JFM, see [Siegmund-Schultze 1994]. Note that economic hardship in Germany after the war probably reduced the reviewing activity of the JFM.

${ }^{12}$ Recent studies about the interwar mathematical community in France have also contributed greatly to the revision of accepted wisdom about postwar French mathematics; see Juliette Leloup's doctoral thesis [Leloup 2009] and a special issue of the Revue d'histoire des sciences [Beaulieu 2009], and esp. [Goldstein 2009, Gispert \& Leloup 2009].
} 
the "Weimar culture." Forman is indeed one of the few historians to suggest that the period of WWI might have had an appreciable effect not just on the organization of science, but also on some of its basic principles - and what effect: acausality, quantum mechanics, and so on! In Forman's article war appears as the last glitter of a golden age, now irredeemably lost. This was a time when scientists could share sentiments with "the rest of the German public" [Forman 1971, p. 8]. Indeed, they might have been even more optimistic than most and feel "self-confidence and selfsatisfaction due to their contributions to Germany's military success and to their anticipation of a postwar political environment highly favorable to the prosperity and progress of their disciplines" (p. 8; original italics). In the last months of the war, Felix Klein mapped out a glorious and harmonious future where government money would seal the alliance struck between the university and the military (p. 9).

The cultural movements discussed by Forman (Lebensphilosophie, neoromanticism, antipositivism, belief in acausality) are "intellectual currents, whose sources lay in the prewar period, but which welled up immediately following Germany's defeat, continued to dominate the intellectual milieu in the mid-1920's as in the first years of the Weimar Republic" (p. 18). Only in the "radically rearranged scale of values ascendant in the aftermath of Germany's defeat" (p. 6), those undercurrents could forcefully emerge. Buried by the discipline, hopes, and requirements of war, a persisting "subterranean acausality current" (p. 67n) was allowed to spring out and become mainstream in German culture after the Armistice. Forman most clearly expressed the reason for which prewar marginal beliefs could take the center stage in the postwar when he approvingly quotes Arnold Sommerfeld: "The belief in a rational world order was shaken by the way the war ended and the peace dictat" [Forman 1971, p. 13]. The irrationality of defeat, more than the absurdity of trench warfare, induced people, including prominent scientists, to relinquish earlier faith in rationality and determinism and to embrace acausality. ${ }^{13}$

In short, while the Bourbaki thesis is an account of social hindrances standing in the way of scientific progress, the Forman thesis claimed that social anxieties gave rise to new scientific principles. Paradoxically, as opposed to the Forman thesis, the Bourbakis saw the war as a cause for tightening the clutch of outmoded representations of science, blocking the way to modernity. But since we have hinted at the fact that it is not war itself but defeat that actually is central in Forman's argument, the paradox may only be apparent: it seems to make sense that opposite national experiences regarding the end of the war would lead to opposite reactions in scientific communities.

Ultimately, both theses however make the war disappear. In the Bourbaki thesis, as already noticed, nothing else than the death of a few young mathematicians is held as significant for the history of mathematics. In Forman's paper, similarly, the striking war experiences of two of his major protagonists, Hermann Weyl and Richard von Mises, are not discussed. Weyl's whole year of military service in the German Army near Saarbrücken, his release at the request of the Swiss Government in May 1916, and his taking refuge to neutral Zurich are all left without mention. ${ }^{14}$ Similarly, Forman does not think worthy of discussion the fact that von Mises was intensely involved with aviation throughout the period: as technical

\footnotetext{
${ }^{13}$ Another example where scientific concepts might have been inspired by the war experience might be the emergence of the "polar front" in meteorology [Friedman 1982].

${ }^{14}$ Norbert Schappacher, "Selflimitation \& Holism in Mathematics: The example of Hermann Weyl and World War I," talk at the meeting on "Mathematics and Mathematicians through
} 


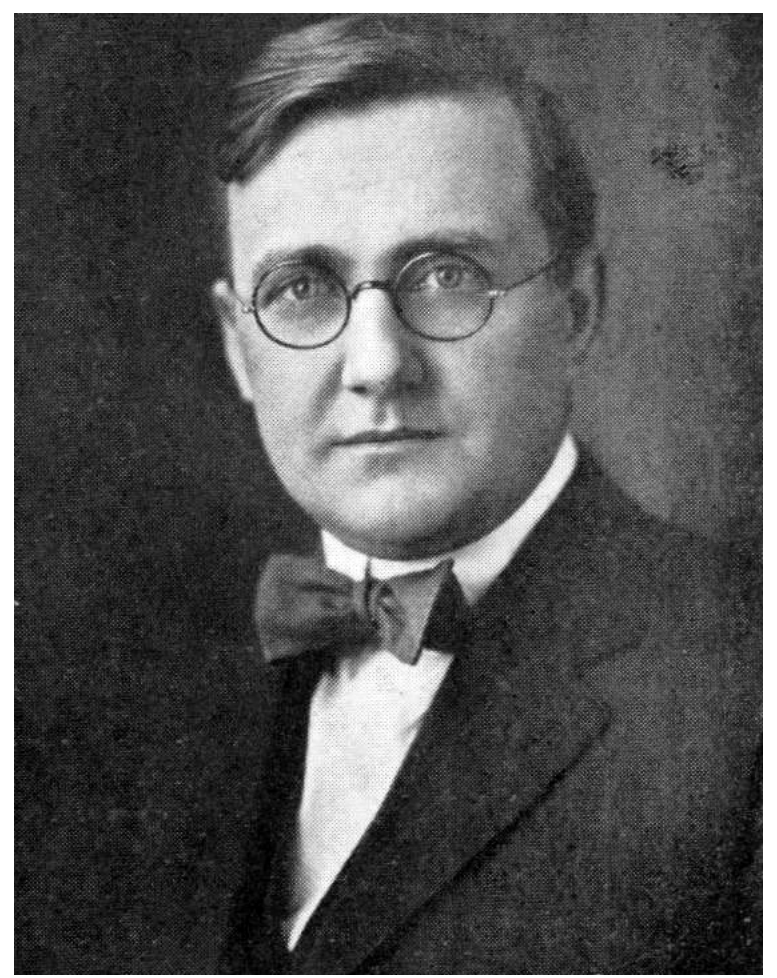

Figure 5. Lester Randalph Ford in 1925. Courtesy of the Archives of Rice University, Austin.

advisor to the nationalistically and militaristically informed "Prinz-Heinrich-Flug" race in 1913-14, as one of the first to be awarded a pilot's licence from the German Nationalflugspende in 1914, as an officer of the Austrian air force during the war who served actively, who was involved in the conception of the first Grossflugzeug (a 600-horsepower airplane), and whose lectures about flight theory to Austrian officers, Fluglehre, were published in 1918 and went through several editions (the English translation still being in print) [Siegmund-Schultze 2004]. Fighting, defense work in which mathematicians might have been involved, are nowhere brought up by Forman. In both theses, the effect of war mainly comes from the losses it brought about: the loss of a generation of mathematicians or the loss of trust in rational determinism and prewar values. How experiences during the war have brought about these new situations after the war still has to be explored. This is the purpose of this book.

\section{Varieties of War Experience}

The experience during the war of the man of science has sometimes been confusing [Hale 1919, p. 143].

World War I" held at the Centre international de rencontres mathématiques (CIRM) in Luminy, Marseilles, January 21-26, 2007. 
2.1. Americans in Paris. In the summer of 1914, Lester Randalph Ford was appointed lecturer of mathematics at the University of Edinburgh (fig. 5). A native of Missouri, Ford had studied under Maxime Bôcher at Harvard, graduating with an M. A. in 1913. He had come to Edinburgh with a travelling fellowship to work with Edmund Taylor Whittaker. The student magazine The Gambolier stressed how unusual this appointement was: "It is not often we fill up vacancies in, or augment the staff of, our University from across the Atlantic." At a time of war, Ford was introduced as a man who "like the proverbial nation, is happy in the fact that he has no history. So far as we have been able to discover, he has never killed a man." ${ }^{15}$ Working on functions theory, Ford originally intended, as he wrote in a letter to Birkhoff on 25 January, 1915, to go to Cambridge and Paris. Although travel was difficult at the time, Ford managed to reach Paris later in 1915 only to find that mathematics was not on anybody's mind. On 12 December, Ford shared his disappointment with Birkhoff: "The university has commenced in a half hearted sort of way, but there is nothing that I am interested in beginning until January. I had expected to attend [Gaston] Darboux's course on Géométrie Supérieure, but although scheduled to begin Nov. 5 it has not yet started." 16

Half a year later, the United States was still officially neutral and another mathematics student from Harvard was thinking of traveling to Paris to learn mathematics! After his Harvard Ph.D. thesis on integral tests for the convergence and divergence of infinite series, Raymond W. Brink was awarded the Sheldon Travelling Fellowship. But, again, he found that, as a center for the study of mathematics, Paris was in much disarray. On 11 November 1916, Brink wrote to Birkhoff: "I have been waiting to write you until things at the Sorbonne were sufficiently settled for me to give you some idea of how my work would go here. Until the middle of last week it was impossible to obtain any information as to what courses would be given, or by whom." ${ }^{17}$ Brink went on:

I am much disappointed in affairs at the Sorbonne. There are, to tell the truth, no courses at present that interest me in the least. I go to a course of [Édouard] Goursat's on Mathématiques générales, for the sake of what inspiration I can get from that gentleman, and to acquire a mathematical vocabulary in French. I must say that the course itself is not very interesting. Goursat and [Henri] Lebesgue are giving courses such as differential calculus, and no advanced courses at all. In December the Collège de France opens and Hadamard and [Georges] Humbert give courses on partial differential equations and on Abelian integrals, respectively, that from their description in the programme should be interesting. [...] The second semester, according to Borel, Picard and Goursat will give

\footnotetext{
${ }^{15}$ Lester Ford, M.A., Lecturer in Mathematics, University of Edinburgh, The Gambolier 7 (Wednesday, 27 January 1915), p. 140; quoted from J. J. O'Connor and E. F. Robertson, "Lester Randolph Ford," MacTutor History of Mathematics archive, http://www-history.mcs.st-andrews.ac.uk/Biographies/Ford.html (last accessed 5 November 2012).

${ }^{16}$ Ford's letters in [Birkhoff Papers, HUG 4213.2, box 7]. Note that Darboux was to die on 23 February 1917, at age 74. In the chapter by Aubin, Gispert, and Goldstein dealing with Paris mathematicians, we see that this was precisely the time of the largest effort at reorganizing war-related scientific research and that mathematicians were especially involved in this.

${ }^{17}$ Brink's letters to Birkhoff in [Birkhoff Papers, HUG 4213.2, box 7].
} 
advanced courses at the Sorbonne, but nobody knows as yet what the subject will be.

Although war was raging not more than a hundred kilometers away, course offerings seemed relatively diverse in the French capital. But Brink went on to describe "how badly shattered the system at the Sorbonne is by the war." Courses by Borel and others had been announced at the ENS, so Brink went to enquire about it: "The very pretty, very amiable, and very ignorant young lady who is the information bureau said she knew nothing about these courses, and agreed with me that this notice, and the fact that the École was closed on account of the war, seemed to present an amusing paradox." Going the ENS to try if he coud not see Borel, Brink only found the doorman.

[T] he concierge said M. Borel was not there, but was at the Ministère des Inventions. No, he did not know where that was, but anyway M. Borel was there. A gendarme was of the opinion that the Ministère des Inventions was with the Ministère of Public Instruction, corner of rue de Grenelle and rue de Bellechasse, in which opinion he was confirmed by an important looking bearded person who was just entering the Mairie of the Vme Arrondissement. I walked the several kilometres to the corner of rues Grenelle and Bellechasse. A belle chasse it proved to $\mathrm{be}^{18}$, for the concierge at this place "forwarded" me to another address 30 minutes away, where at last I really found M. Borel. He received me very pleasantly, apologized for the disordered state of things, refrained from laughing when I invented new French words, said that the notice of courses on the bulletin was merely a meaningless remnant from preceding years, that no courses would be given at the École, that he regretted his inability, on account of the war, to teach me anything about series, that my best chance for mathematics was to wait for the courses I have mentioned [by Goursat and others], and said "au revoir."

Paris was not proving to be a very convenient place where to learn mathematics. ${ }^{19}$ "Libraries that are open only four or five hours a day, and hotel rooms that are too cold to work in, courses that not even professors took seriously, and the general atmosphere of lack of interest and absorption in the war, were very disappointing," Brink complained to Birkhoff on 21 January 1917.

For Brink, luckily, things took a turn to the better. Courses he was finally able to take from Humbert and Hadamard proved to be worth while. Going back to the United States, Brink was immediately offered a position at the University of Minnesota [Olmsted 1974].

But the atmosphere in Humbert's class at the Collège de France must have been peculiar. One cannot help wondering about a possible encounter between Brink and his contemporary, Gaston Julia (figure 6) who was about to defend a doctoral thesis, in December 1917, on topics close to Humbert's interests. A brillant student at the ENS, Julia was now disfigured by gunshots received on the front in 1915. But two

\footnotetext{
${ }^{18}$ Literally, a "beautiful hunt."

${ }^{19}$ Another case of major disruption of the university life brought about by WWI is discussed in Laurent Rollet and Philippe Nanbonnand's contribution to this volume focusing on the university of Nancy.
} 

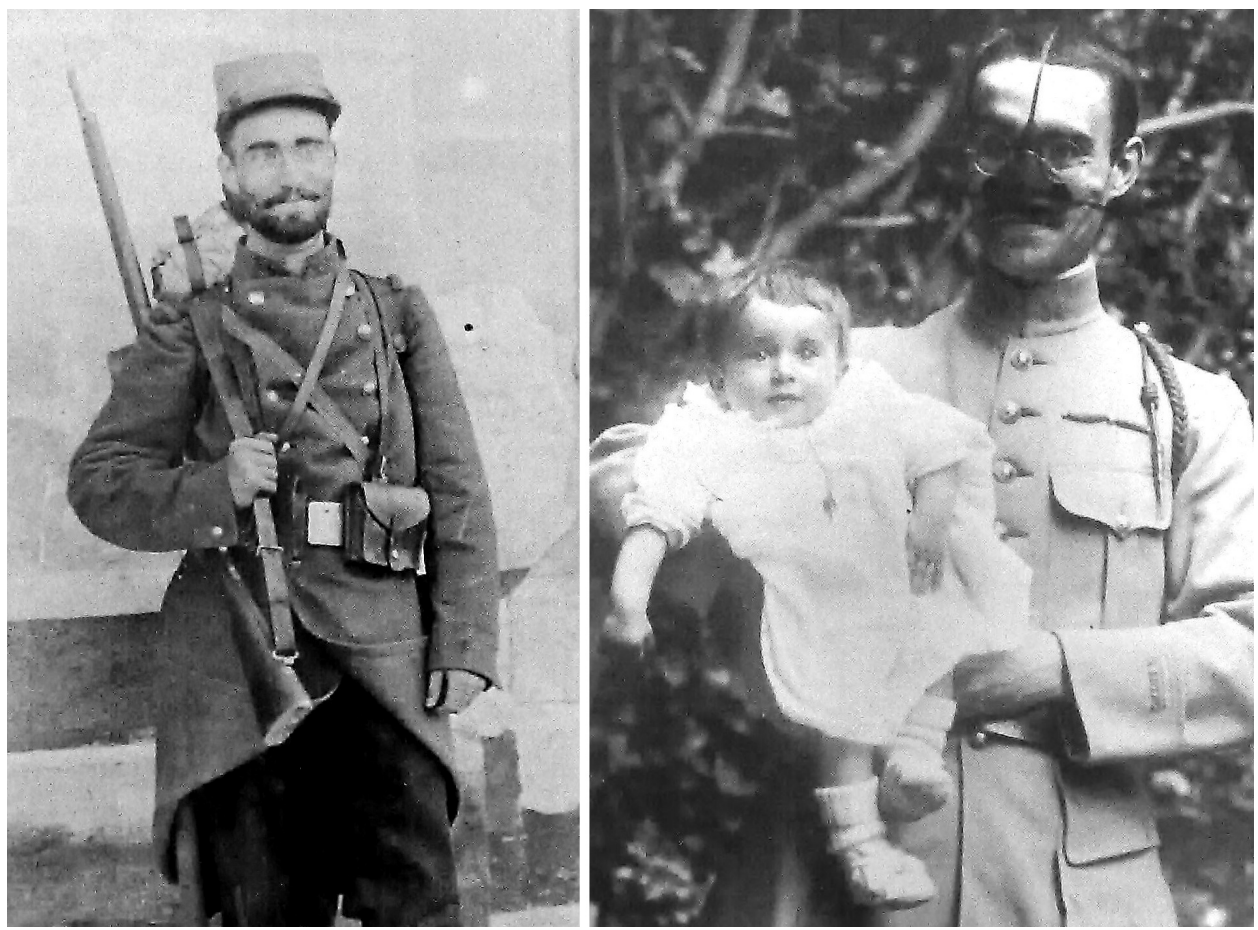

FiguRE 6. Gaston Julia in uniform: in 1914 before he was sent to the front; and in 1919 after his release from the Val de Grâce hospital. Source: Science et monde 150 (1934), p. 195.

years later, "between violent headaches, frequent bandages and operations," soon to be declared "100\% invalid," he was attending Humbert's lectures, too. ${ }^{20}$

In 1917, Ford also came back to the U. S. where he defended a Ph. D. thesis on closely related themes, in which he expressed his "indebtedness to Professor Humbert of the Collège de France, who suggested" the subject to him [Ford 1918, p. 2]. Brink and Ford however were caught up by war: when their country joined the fight both became mathematics instructors for army recruits. Before he was recruited at the Rice Institution, Austin, Ford wrote a mathematics textbook for gunners [Ford 1919] to which we shall come back. ${ }^{21}$

2.2. Experiences. Age, country, field of specialization, health and social status were determinant factors in the way in which mathematicians lived through the war. Some were drafted and spent five years in the mud; they got killed and died of illness; they were wounded or taken prisoners; some lost sons and students. For others, the war provided new opportunities to apply their knowledge and skill in unsuspected directions, to have inspirational encounters with people they might not have met otherwise, to shift drastically their fields of interest, to get involved in science policy at the national and international levels with an effectiveness they might not have dreamt about earlier or to become influential public figures.

\footnotetext{
${ }^{20}$ See Catherine Goldstein's contribution to [Goldstein \& Aubin forthcoming].

${ }^{21}$ For more on the mobilization of American mathematicians, see the contribution by Archibald, Fenster, and Kent in this volume.
} 
The variety of experiences is matched by the variety of relevant sources that can be used to try and reconstruct them. Scattered in the secondary literature on the history of mathematics of this period are countless hints on the way in which the war affected the life and work of mathematicians. Journals of the time, mathematical or not, correspondances and military documentation host many examples of their military work and of various instances of mathematical techniques being innovatively applied on the front, in general staff, or in ministries. This dispersion of sources is a major difficulty which confronts the historian wishing to make sense of these wartime experiments.

But also, like Julia's or Ford's, every wartime trajectory is unique. When we look at both of their future work, Humbert's mathematical influence seems greater than their own war-related activities, which could hardly have been more at odds. Reciprocally, common war experiences lead to completely opposite reactions. While the loss of his sixteen-year old son in fighting near Arras may have killed Göttingen differential geometer Paul Stäckel [Renteln 1997], Émile Picard's cruel loss of three sons strengthened his hatred of the German and his resolve to act upon it by excluding them for postwar international organizations. As "a refuge from immediate fact," Alfred North Whitehead dedicated his influential Enquiry concerning the Principles of Natural Knowledge - "thought out and written amid the sound of gun [...] a refuge from immediate fact"- to his son Eric Alfred killed in action over the Forêt de Gobain [Whitehead 1919, p. viii]. The German mathematician Oskar Bolza who had spent more than 20 years in the U.S. also was deeply affected by WWI: the author of a classic text on the calculus of variations practically abandoned all mathematical research for over ten years and devoted himself to the study of religion and Sanskrit authoring a book titled Glaubenlose Religion under the pseudonym of F. H. Marneck [Bliss 1944]. By contrast, the Liverpool professor of mathematics William Henry Young was said have been driven back to mathematics "as a drug" by his son Frank's death in 1917 [Hardy 1943, p. 310]. ${ }^{22}$ And if both Jacob Klein and Thomas Heath delved into Ancient Greek mathematics, the first sought to understand the roots of the symbolic modernity that had made this war possible while the second took refuge with those Greeks who had "desist[ed] from war and wickedness" [Klein 1934, Heath 1921].

Without engaging in overly theoretical arguments, we would like to claim that a close look at wartime experiences, however diverse they may be in terms of events and reactions to them, is an essential step toward a better understanding of shifting professional identities and disciplinary values in the postwar years. Of course, the concept of experience in historiography is notoriously controversial, particularly in the context of WWI [Mosse 1991, Audoin-Rouzeau \& Becker 2000, Horne 2005]. Our objective here is not to define a single war experience linked to mathematics, but rather to provide a preliminary survey of mathematicians' multiple, concrete experiences during the war. We concur with the historian Joan Scott in her opinion according to which, counter to common perceptions, "it is not subjects who have experience, but subjects who are constituted through experience. Experience in this definition then becomes not the origin of our explanation, [...] but rather that which we seek to explain, that about which this knowledge is produced" [Scott 1991, p. 779-780]. The effort to reconstitute mathematicians' wartime experiences and confer historical meaning to this scattered amount of evidence will

\footnotetext{
${ }^{22}$ See also [Grattan-Guinness 1972, p. 153-156].
} 
perforce lead us to revise our definitions of what constitutes a mathematician and what properly belongs to mathematics.

2.3. In the Trenches. The number of mathematicians who served as soldier in WWI will never be known with precision. Just like the great majority of their contemporaries, they carried a gun to the trenches and suffered horribly. "The wounded men," remembered an American hospital worker, "they smell of sweat, camp-fire smoke, leather, and tobacco - all the same, whether the man be a peasant or a professor of mathematics." ${ }^{23}$ Evidences we have from their campains are many and range from the sadly banal to the heroic and extraordinary. They give flesh to the characteristic features historians of the Great War have already indentified: the boredom of months without end spent in muddy trenches, the violence of the attacks, the pain of resulting injuries and death. ${ }^{24}$

The young Willi Böhle, born in 1897, had studied mathematics at the University of Freiburg before the outbreak of WWI. On 15 April, 1915, he wrote his family from the trenches:

darling little mother, and you too, my brother and sister, I am ready to endure anything for your sakes, so that you may never see what ruined villages and shell-destroyed fields look like; so that you may never learn what the word war really means. Be thankful, my Gretel and Erich-although you are still so young and know nothing of the serious side of life - that our little house is still standing; that you can sleep in beds; that you have a roof over your heads; that your are not tormented by vermin; that you have your meals at the proper times; that you do not know what thirst and hunger are. Be thankful; fulfil all your little duties conscientiously, and never grumble! [Witkop 2002, p. 331]

Conditions experienced on the other side of the no-man's land were the same. No less characteristic, if lighter in tone, was Julia's account in a letter to Borel written on 21 January, 1915:

Life in the trenches is certainly lacking in terms of comfort and mud and water are things most often encountered. We are nose to nose with the Germans, at less than 100 meters. The Germans fire on our positions [...]. Nevertheless, we keep busy by reparing our shelters $[\ldots]$, by cleaning access tunnels and surveillance trenches, by long conversations with colleagues from the batallion, leaving us little leasurely time during which the reading of a book is appreciated. Nonetheless, a more active life would be preferred. But whan can you do! $!^{25}$

\footnotetext{
${ }^{23}$ Testimonial by J. H. G. in [Collective 1916]; available online http://www.gwpda.org/ medical/FriendsFrance/ff03.htm (last viewed 3 November, 2009).

${ }^{24}$ The war correspondance between Julia and Borel provides a good illustration of this, as well as concrete details about the military assignments of ENS students [Borel Papers, M143-M154].

25 "La vie aux tranchées manque certainement de confortable et la boue et l'eau sont les choses du monde qui s'y rencontrent le plus souvent. Nous sommes nez à nez avec les Allemands, à moins de 100 mètres. Les Allemands tirent sur nos créneaux [...] Malgré tout, on a de quoi faire avec la réfection des abris, [...] le curage des boyaux d'accès, de ronde, les conversations fort longues avec les collègues du bataillon, laissant un peu de loisir, pendant lequel la lecture d?un livre intéressant est appréciée. On voudrait tout de même une vie plus active. Mais qu'y faire!" [Borel Papers, M151]. This correspondence is discussed in the reference given in footnote 20.
} 
It was ten days later that, as mentioned above, Julia who meanwhile was sent to a "more active" sector sent news he had been hit in the face by a bullet shot at point-blank range [Borel Papers, M152]. Böhle, for his part, was killed on 26 May, 1917, near Arras. These are just a few of the countless examples of mathematicians who were not left unscathed from their participation to frontline actions. The German algebrist Alfred Brauer (the older brother of Richard Brauer) was severely injured, as was the Scottish mathematician Raymond Keiller Butchart who lost a leg. One remembers Courant, of course, who was badly shot: "it is miracle I survived" [AIP 1962]. In fact, being wounded was often the only opportunity for many mathematicians to leave the front line and return to science, either pure or applied to war. Konrad Knopp was wounded as early as September 1914 and before the end of the year, he was teaching in Berlin and working on point-set theory, later partaking in setting up the Mathematischer Zeitschrift in January 1918 [Kamke \& Zeller 1957]. The Austrian statistician Wilhelm Winkler was twice wounded before being invited by his former teacher, now minister of war, to join the scientific committee he had set at the ministry. The case of Antoine, who was mentioned earlier, shows that serious wounds hardly garanteed a safer position: even though he had been wounded twice in 1914, the ENS mathematician was sent back to front duty from which he was finally released after having lost his sight.

On 22 June 1918, the mathematical seminar of the university of Rome honored the memory of fours professors of mathematics in Italian universities who had died in battle [Collective 1918]. Luciano Orlando was a privatdocent in mathematical physics at the university of Rome and Ruggiero Torelli a privatdocent in geometry. Both died on the battlefield of the Isonzo in August 1915. The tragic fate of Eugenio Elia Levi, professor of differential calculus at the university of Genoa stroke his contemporaries. ${ }^{26}$ Even his specialty as teacher of theoretical geodesy could not save Adolfo Viterbi, of the university of Pavia, from an untimely death while on a delicate topographical mission. British wranglers were also killed.

In Germany and Austria, contrary to Dieudonné's claim, many are the members of the German Mathematicians' Association [Deutschen Mathematiker-Vereinigung $(\mathrm{DMV})]$ who were killed on the battlefield. Anton Lackner, privatdocent of descriptive geometry at the Technische Hochschule in Vienna fell before Cracow in November 1914. A former extraordinary professor of applied mathematics and technical physics in Jena, Rudolf Rau born in 1871 died on 17 December 1914. Privatdocent at Göttingen, Dr. Wilhelm Behrens who was close to Felix Klein died on 23 June 1917. To this list, one may add the names of Wolfgang Wilhelm Vogt (Heidelberg University), the number theorist Edmund Busche (Hamburg), the director of Zeitschrift für mathematischen und naturwissenschaftlichen Unterricht Ernst Grimsehl, a physicist, who died at 53-years old in Langemark near Ypres on 30 October 1914, and the list unfortunately could go on. ${ }^{27}$

Some mathematicians also fell as indirect casualty and died of illnesses caused by the war. The Polish topologist Zygmunt Janiszewski who had received his doctorate in Paris fought for the independance of his country and went on to establish the Polish school of mathematics and the journal Fundamenta Mathematicae. He

\footnotetext{
${ }^{26}$ Levi's brief carreer is discussed in Pietro Nastasi's and Rossana Tazzioli's contribution to this volume.

${ }^{27}$ Most of this information was gathered from the war issues of the Jahresbericht der deutschen Mathematiker-Vereinigung.
} 

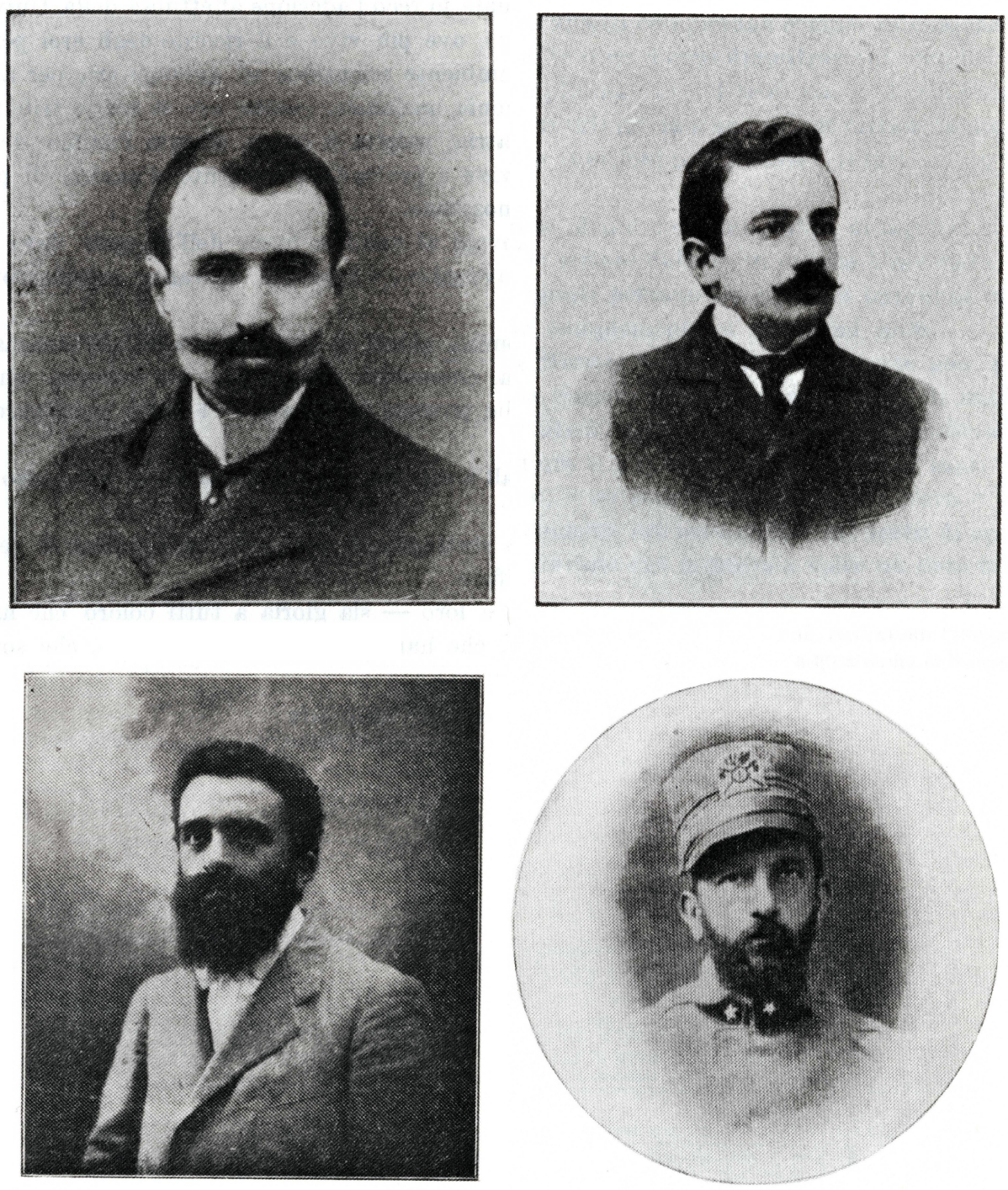

Figure 7. Four Italian university professors of mathematics who died in battle. Upper right: Luciano Orlando (1877-1915); upper left: Ruggiero Torelli (1884-1915); lower right: Eugenio Elia Levi (1883-1917); lower left: Adolfo Viterbi (1896-1917). Photos taken from the commeration at the Mathematical Seminar in Rome [Collective 1918].

died from the flu epidemic of 1920 [Feferman \& Feferman 2004, p. 28]. Better known is the case of Srinivâsa Aiyangâr Ramanujan. When he reached Trinity College,Cambridge, in 1914, working conditions there left much to desire. He wrote back home: 
I am very slow publishing my results owing to the present war. A lecturer here whom I know well and from whom I received some help to publish my results has gone to war. The other professors here whom I know have lost their interest in Mathematics owing to the present war [Berndt \& Rankin 1995, p. 112]..$^{28}$

According to his biographers, Ramanujan who was a strict vegetarian suffered from a vitamin deficiency during his time in England. He never recovered from his illness and died in India on 26 April 1920.

In the mathematical community, the tragic loss of young promising colleagues was felt dearly. Herbert Herkner was a gifted mathematics student Max Born had met in Göttingen. Upon hearing that Herkner was serving on the front, Born tried to bring him to the Artillery Testing Commission [Artillerie-PrüfungsKommission, hereafter APK] in Berlin. But Herkner was notified of his new assignment just one day before the battle of Cambrai where he was killed on 22 November, 1917. Heart-broken, Born remembered in glowing terms the impression left by Herkner's coming to Göttingen:

This was an appearance that filled all the colleagues who came into contact with him with reverent wonder and with the hope to see a revival of mathematics arise through him. A tragic destiny has destroyed this hope like so many others. [...] Just like the gratitude over the services of a busy life deserves an obituary, the mourning over burried hope must find an expression. This is the objective and the sense of these lines [Born 1918, p. 179-180].

In France, altogether 22 mathematicians, licenced mathematics teachers [agrégés], and graduates from the ENS died in combat, among them Jean Merlin (Lyons Observatory), Alphonse Blondel (Toulouse Observatory), and René Gateaux. ${ }^{29}$ Their disappearance left Borel, who "found the school haunted by shadows," unable to resume his scientific directorship of the ENS [Marbo 1967]. After the death of Georges Lery, a specialist of Green functions, Hadamard wrote: "For a certain number of years, there has been in France a remarkable school of young mathematicians, thanks to which our country fear, on that ground, no comparison. [...] Without possible contestation, Lery has won for himself a position in this phalange" [Hadamard 1916, p. 115]. Julia similarly wrote a touching obituary for his "prodigiously loving friend," the young Paul Lambert born in 1894 and killed on 13 March 1915, not two months after Julia himself had sustained his devastating injury. This is a touching document in which Julia vividly recalls his love of life and his intellectual capabilities. With Borel's nephew and adopted son, Fernand Lebeau, and other now deceased classmates, Julia wrote, they formed a joyous band, cycling around Paris, reciting poetry, and working on mathematics. About his friend's broken future, Julia wrote:

It would be adventurous to make prognosis, and I cannot here put side by side my friend and such an authentic and indisputable glory as Galois, but I cannot refrain from saying that I often thought of this immortal genius by living close to Lambert: they had many

\footnotetext{
${ }^{28}$ The lecturer that had helped Ramanujan and went to war was J. E. Littlewood. More detail about his involvement in the British war effort can be found in Barrow-Green's contribution to this volume.

${ }^{29}$ On French casualties among mathematicians, see [Aubin, in preparation].
} 
resemblances in their taste, they were both very precocious, they

both died very young and tragically [Julia 1919, p. 110].

It is indeed impossible to evaluate what the fallen might have been able to accomplish, even if the discussion was recurrent among surviving contemporaries, and even more difficult perhaps to understand the effect of their loss on the development of mathematics. During the war, however, many wanted to believe that the sacrifice was worthwhile. In a formal speech delivered in December 1915, the President of the Academy of Sciences Edmond Perrier for example praised the way young students had volunteered and fulfill a useful service to the nation. "They remember that the most educated must lead by example; they will be the first to [...] run toward the barbed wires, the first to die [Perrier 1915, p. 804; our emphasis].

In the interwar period, the value of such sacrifice became less obvious to Hadamard or to Julia, who both exterted a strong influence on Bourbaki mathematicians, opening their seminars to many of them. With the massacre of so many talented mathematicians, they acutely felt the burden: "the dead [...] are for the living a reason to live in order to take their place and fulfill the task that was taken from their hands" [Julia 1919, p. 113]. Gateaux' papers in functional analysis, for instance, were transmitted to Paul Lévy, who carried on his work with great success, although in the framework of probability theory. ${ }^{30}$

Let us consider then the case of Jean Clairin. Before the war, Clairin was a professor of mathematics at the university of Lille; he was killed in battle near Cambrai, as early as 26 August, 1914: "his forehead, his noble forehead, broken by a bullet." ${ }^{31}$ In his thesis in 1902, Clairin had investigated Bäcklund transformations which allow to find other solutions to a partial differential equation once at least one solution is known. In the following years, Clairin published several articles (references of which can be found in [Lamb 1976]). Before the war, he had announced some results in the $C R A S$ without providing complete demontrations. In 1920, Émile Gau received some of Clairin's papers which were in great disorder after the German occupation of Lille and arranged for their publication [Clairin 1920]. Then Clairin's work - and indeed Bläcklund transformations altogether - fell into oblivion until the method developed by Clairin was applied by George L. Lamb in 1974 to the Korteweg-deVries and nonlinear Schrödinger equations and after much delay became a mainstay of soliton theory [Lamb 1974]. Lamb attributed this delay to WWI: "Bäcklund transformations ceased to be an active area of research after World War I. Undoubtedly this was due, at least in part, to the demise of those active in the field (e.g. Clairin)" [Lamb 1976, p. 76]. However, as in Antoine's case, it appears that a bit more than simply the death of promising mathematicians was at play: Édouard Goursat devoted a book to Bäcklund transformations in 1925 [Goursat 1925], and one is then left to ponder upon the change of mathematical priorities during the interwar period [Leloup 2009].

In the trenches, mathematics often provided a welcome distraction to fighting men. Recently appointed dozent at the Budapest University, Zoárd Geöcze who had defended his doctorate in Paris in 1910 found time to write papers on the theory of surfaces which he sent back via military post. First sent to Serbia where

\footnotetext{
${ }^{30}$ This development is explained in greater details in Laurent Mazliak's contribution to [Goldstein \& Aubin forthcoming].

${ }^{31}$ [Ollivier 1917, p. 85]. On Clairin, see also [Pourprix 2009, p. 42, 55]. There is an obituary by his mentor [Goursat 1916].
} 
he survived a crushing defeat, he became mortally ill in Ukraine. After his death in 1916, his colleague Loránd Eötvös wrote: "no horrors of the trenches or the thunder of guns were able to distract Zoárd Geöcze from concentrating on the solution of his favourite problem and making efforts to widen and deepen our knowledge of the subject" [Szénássy 1992, p. 322].

"At rest, [...] after my correspondance with my family, mathematics provide me with the best distraction" [Lhermitte 1917, p. 90]. In this letter, Théophile Rousseau who was a mathematics teacher in Rennes testified to the fact that his former training offered little more than a welcome escape from the harsh realities of combat. The author of several articles about vector analysis for the teaching of geometry, Rousseau died on the front line after he was hit by shrapnel on 11 April 1916, without having been asked to put his mathematical skill to better use for defense.

Better known and equally tragic is the frontline experience of Karl Schwarzschild. Volunteering in August 1914 Schwarzschild served in Belgium and France where he was in charge of a weather station and of computing ballistic trajectories. Sent to the Russian front, he found the time and resources to author two papers on Albert Einstein's relativity theory and one on Max Planck's quantum theory. The latter paper explained that the Stark effect, namely the splitting of the spectral lines of hydrogen by an electric field (the amount being proportional to the field strength), could be proved from the postulates of quantum theory. In November 1915, he contributed to the Berlin Academy a paper on "The Effect of Wind and Air-Density on the Path of a Projectile," a theme more directly connected to his present environment. Schwarzschild's relativity papers give the first exact solution of Einstein's general gravitational equations, stating what the geometry of spacetime near a point mass should be. As he wrote to Einstein on 22 december, 1915, war "was kind to him," because despite "heavy artillery fire in the far," he had been able to enjoy "a stroll through [Einstein's] land of ideas." 32 While in Russia, however, Schwarzschild fell ill to a rare autoimmune disease of the skin from which he died in $1916 .^{33}$

2.4. Prisoners of War. As prisoners of war. The publication in May 1916 of an article by a prisoner of war in Hohen-Aspurg with the solution to a mathematical problem posed earlier that year by the professor of geometry at the École polytechnique Maurice d'Ocagne in L'enseignement mathématique show that some prisoners had access to mathematical journals and able to enjoy a correspondence [Barolet 1916]. In 1916-1918, several Hungarian young men, prisoners of war in the camp of Berezowka in Siberia decided to organize a mathematical seminar. The most advanced mathematician of the three was Eduard Helly who had proved the Hahn-Banach theorem in $1912 .{ }^{34}$ Voluntarily enrolled in the Austrian army, he was shot in the lungs in September 1915 and taken prisoner. About the camp, an American relief worker wrote in 1918:

\footnotetext{
${ }^{32}$ Gesammelte Werke, vol. 1, p. 38. The way in which Schwarszchild kept in touch with recent development in general relativity in discussed in [Rowe 2004, p. 110]. For a short discussion of Schwarzschild's ballistic paper, see [Eddington 1917, p. 315].

${ }^{33}$ Mathematicians also occupied their minds with extra-mathematical activities. Drafted in the Austro-Hungarian Army in 1915, Eduard Čech used the next three years to learn Italian, German, and Russian, skills he could draw on during his carreer as a world-class topologist.

${ }^{34}$ Note that the Austrian mathematician Hans Hahn was himself severely wounded in 1916.
} 
In every camp we had a school, according to the size and need, enrolling from two hundred to seventeen hundred students, with as many as forty courses, ranging from reading, writing and arithmetic, to advanced modern languages, Latin, Greek, and Hebrew, Physics, Philosophy and Psychology [...].

In the great camp at Berezowka, at that time consisting of eighteen thousand prisoners, I started a library of one hundred and five volumes, the last foreign books to be had at Irkutsk. During the succeeding months, as the library grew, although we had a limit of one day for the borrowing of books, there were often thirty or forty men turned away, with not a book in the library. At the time that I left Siberia, a few months ago, we had in this camp more than four thousand volumes, with a central and two branch libraries. As there are several thousand students and professors and men of the university class in this camp, the importance of the school and library can scarcely be overestimated. Such men are much more liable to nervous breakdowns than the uneducated, so that the occupation thus given has saved many a mind agonies which sometimes end in insanity. Not only this, but many of the men have been able to carry on their education and fit themselves better for life and service after the war while confined in these prison camps [Morgan1918, p. 9-10].

To pass time, Helly taught mathematics to his fellow captives. His lessons to Tibor Radó who had been studying civil engineering before the war proved so inspirational that when after an adventurous trek through polar regions he was able to resume his course of study at the university of Szeged in 1920, Radó chose mathematics. We may have an inkling of Helly's teaching in the wartime mathematical reflections published by the young Heinrich Elbogen, another Austrian captive who met Helly in Russian prison camps. In his preface to Elbogen's book titled "The Axiomatic Method in Mathematics," Helly wrote that those reflections was written at a time when the author was under "dreadful physical and psychological stress." To Helly, memories of war captivity in Russia were painful, he said, and "one of the rare lightspots was to have met Elbogen there" [Butzer et al. 1980, p. 145, n. 12$]{ }^{35}$

The case of the French mathematician Henri Eyraud studied by Jim Ritter presents some similarities with a happier outcome. ${ }^{36}$ Taken prisoner by the Germans, he was finally released in neutral Zurich, where he was able to pursue his scientific training at the ETH. Before the war, Eyraud had attended the university of Lyons and passed the certification exam to become a mathematics teacher [agrégation] in 1913. His stay in Zurich where he attended Marcel Grossman's and Hermann Weyl's lectures, respectively on descriptive and projective geometry and

\footnotetext{
${ }^{35}$ See Heinrich Elbogen, Die axiomatische Methode in der Mathematik, edited after his death by his mother Alie Elbogen with the assistance of Prof. Oppenheim and Dozent Dr. Helly, privatly printed, Vienna, 1928, a copy of this text is in the Österreich. Nationalbibl. Wien, Signatur 567444-B. I wish to thank Anne-Sandrine Paumier for providing me a copy of the book. On Helly, Tadó, and Elbogen, see also [Butzer et al. 1980, Butzer et al. 1984, Sigmund 2004, Kreyszig 1992, Niriciand \& Becknstein 2007] as well as [Young 1981, p. 327]. For more on the Berezowska camp, see [Rachamimov 2002, p. 99].

${ }^{36}$ See Ritter's contribution to [Goldstein \& Aubin forthcoming].
} 


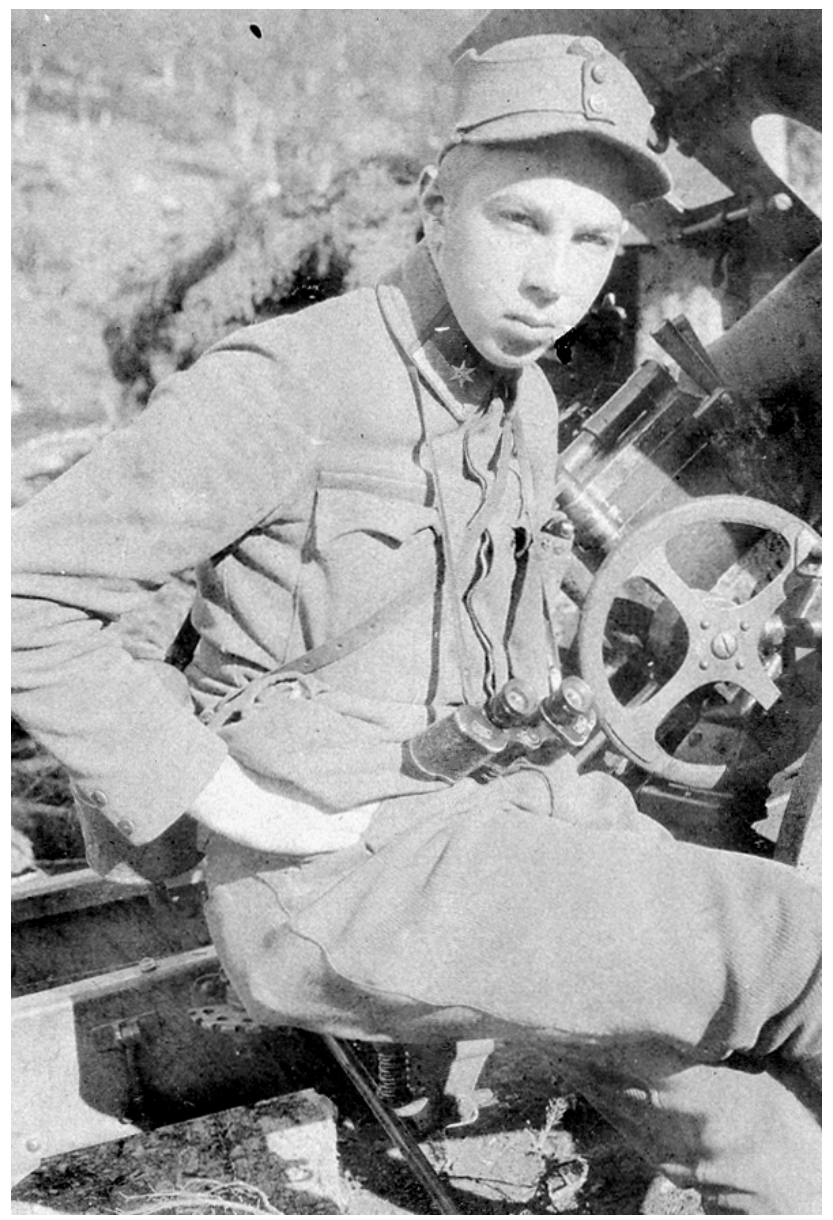

Figure 8. Otto Neugebauer in Austrian uniform in Val Pampoluzzo on the Italian front, 6 October 1918. Tagebuch 19171919 (p. 42), Otto Neugebauer papers, Box 13. Courtesy of the Shelby White and Leon Levy Archives Center, Institute for Advanced Study, Princeton, NJ, USA.

on diffential geometry and electromagnetic field theory, has a tremendous impact on his professional life. In 1926, he defended the first doctoral thesis on general relativity theory in France and later established the Institute of financial and insurance mathematics in Lyons.

Other mathematicians were taken prisoners, including the Polish mathematician Waclaw Šierpinsky whom Nikolai Luzin and Dimitri Egorov managed to get released to join them in Moscow where they began the study of analytic sets. ${ }^{37}$ In an Italian camp after the end of the war, the Austrian artillery lieutenant Otto Neugebauer (fig. 8), later to become the founding editor of both the Zentralblatt für Mathematik und ihre Grenzgebiete and the Mathematical Reviews and one the most important historians of Ancient mathematics and astronomy, met his fellow

\footnotetext{
${ }^{37}$ About mathematics in Moscow at the time, see [Graham \& Kantor 2009].
} 
countryman Ludwig Wittgenstein carrying in his rucksack the manuscript of the Tractatus logico-philosophicus written during his war service, a time when he took refuge in the life of knowledge to ward off the misery of the world. ${ }^{38}$

2.5. Mobilizing Mathematics. The Russian astronomer Aleksandr Aleksandrovich Friedmann, was recently appointed to the Aerological Observatory in Pavlovsk, near Saint Petersburg, when the war broke out. ${ }^{39}$ In a letter to Valdimir Steklov, a specialist of the integration of differential equations from Saint-Petersburg University, written on 5 February 1915, Friedmann wrote:

My life is fairly even, except such accidents as a shrapnel explosion twenty feet away, the explosion of an Austrian bomb within half a foot, which turned out almost happily, and falling down on my face and head, which resulted in a ruptured upper lip and headaches. But one gets used to all this, of course, particularly seeing things all around which are a thousand times more awful.

At the time, the Russian army besieged the town of Przemyśl, occupied by Austrian troops, and Friedmann who had started flying took part in bombing expeditions. Thinking of applying his mathematical skill to the study of bomb trajectories, Friedmann asked Steklov's advice regarding the integration of equations he had obtained:

$$
\frac{d u}{d t}=-a u \sqrt{u^{2}+v^{2}}, \quad \frac{d v}{d t}=-g-a v \sqrt{u^{2}+v^{2}},
$$

where $u, v$ were the components of the bomb velocity, $g$ the acceleration due to gravity, and $a$ a parameter characterizing the shape and weight of the bomb. Bombs, Friedmann explained, could be divided into two classes: very small $a$ or $a \approx 1$. To solve these two cases, he used approximations, expanding in powers of $a$ in the first case and assuming that $\sqrt{u^{2}+v^{2}} \approx v$ in the second case, which, he noted, was "illegitimate."

On 28 February, 1915, Friedmann explained how he used Runge's integration methods to compute results quickly, which although in fairly good agreement with practice made him "uneasy". He added:

I have recently had a chance to verify my ideas during a flight over Przemysl; the bombs turned out to be falling almost the way the theory predicts. To have conclusive proof of the theory I'm going to fly again in a few days.

Despite his relative success in applying his mathematical skills to war, Friedmann deplored his poor working conditions and the obligation he was in to drop research topics that were closer to his heart.

I should say that it is fairly difficult to do investigations in my circumstances, and all kinds of calculations concerning bomb and bomb-sights take a lot of time, therefore I have very little time for the theory of vortices in fluids with changing temperature for which I feel a strong attachment.

Sometimes, such dedication did not go unnoticed and mathematicians were assigned special posts. In 1916, Friedmann was pulled from the front and his

\footnotetext{
${ }^{38}$ On Neugebauer's wartime service, see [Swerdlow 1993].

${ }^{39}$ The following is based on [Tropp et al. 1993, p. 71-77].
} 
mathematical skills were put to use first as an instructor for recruits, then as a researcher in an aeronautical center, until the Revolution broke out in 1917. The Budapest mathematician Geöcze mentioned above was put in charge of a power station and its supplied lines. Likewise, other scientists and mathematicians were assigned special duties in sound-ranging units, computing bureaus, and weather stations.

Whether mathematics should be be mobilized for war however never received a clear-cut answer. For some, mathematics' universalism was drafted in a fight against the war. Bertrand Russell, who felt "more allegiance to mathematics than to the State," as he wrote in a wartime letter [Russell 1988-1995, p. 287] took a high-profile position against the war. On 23 December 1916, for example, he published on the front page of the The New York Times an open letter to recently reelected U.S. President Woodrow Wilson calling for him to intervene in favor of a negotiated peace between the belligerent nations. ${ }^{40}$

In 1914, the American mathematical educator David Eugene Smith published a problem book for children where he tried to "lay before young people in the elementary schools, at the most impressionable age, the fact of the wastefulness of war" [Smith 1914, p. 5]. Smith asked his reader to evaluate the financial loss of human lives due to the great war as well as the lost production due to the 21 million enrolled men. In other sets of problems, the value of battleships was compared to the cost of college tuition, camping trips, baseball tickets, bicycles, etc.

The battleship Alabama cost $\$ 4,665,820$. In 1913 the total receipts of Alabama for higher education amounted to $\$ 533,659$. The cost of this single battleship would have kept Alabama in funds for her colleges, universities and schools of technology for how many years? [Smith 1914, p. 12]

But this attitude was rather rare. To express the apparent contradiction between a belief in science's internationalism and heavy involvement in war-related activities, French scientists were quick to recycle one of Louis Pasteur's bons mots: "If science has no nation [patrie], the man of science must have one" [Pasteur 1888, p. 29-30]. In the preface to his book on integral equations, the Italian mathematician Giulio Vivanti compared national characters:

While our sons fight valorously to liberate Europe from the Teutonic yoke it devolves to us, whose age and strength do not permit to offer arms to our country, to work for its scientific emancipation. A national science is an absurdity and he would be foolish who would refuse a scientific truth because it arose from beyond the Alps or the sea; but the work of scientific exposition and publication can be and ought to be national. Who does not recognize a German treatise by its minute and sometimes wearisome care of particulars, an English by its good-natured and discursive tone, a French by its form which is sometimes a little vague but always suggestive and elegant? ${ }^{41}$

\footnotetext{
${ }^{40}$ Russell's wartime writings are collected in the vols. 13 \& 14 of [Russell 1988-1995]. Other pacifist mathematicians are discussed in Barrow-Green's contribution to this volume.

${ }^{41}$ [Vivanti 1916, p. xiii]; translated and quoted in [Miller 1918, p. 117].
} 
2.6. Intellectuals and Organizers. Even those who defended the tradition of apoliticism among university professors felt the need to justify afresh their usual activity and that still in wartime scientists could be busy with pure research. In 1915, the applied mathematician Carl Runge (who had lost the youngest of his two sons in battle on 21 October 1914, while the eldest was still prisoner of war), emphasized as prorector of Göttingen University what he thought should be university professors' proper conduct during the war:

The gravity of our time is not favorable to scientific work because all of our thoughts are directed toward a single point, the good and pains of our nation. We are inclined to confer meaning to other reflections only insofar as they play a role for the [national] community. The scientist who was used to consider his research self-justified now ponders upon its validity; he tries to clarify the links it has with and the position it occupies with respect to the intellectual life of our people and consequently to justify, in the eyes of the public and his own, that he [still] devotes his effort to it [Runge 1915, p. 400].

At Christmas 1915, Runge distinguished himself in publishing an article about pure mathematics "Dimensionsbetrachtungen" in a volume prepared by the university of Göttingen with an otherwise strong war flavor, the chemist Otto Wallach for example contributing a text titled "Krieg und Chemie" [Busse 2008, p. 112]. But other German mathematicians were less hostile to a subtle expression of their views, even when addressing topics such as "axiomatic thought." In a speech delivered in September 1917 in front of the Swiss Mathematical Society, Hilbert opened with the following words: "In the life of nations, the individual nation can prosper only if it gets along with all its neighbors and the interest of the State requires that not only order prevails within each individual State but also among them; the same goes for the sciences" [Hilbert 1917, p. 405].

The most famous - and commented - instance of scientists taking position, this time in favor of their country's war aims, was the manifesto known in German as the "Aufruf an die Kulturwelt!" dated 4 October 1914. This manifesto defended German military actions in occupied zones, in partucular Belgium. Felix Klein was the only mathematician among its 93 signatories although it is not clear whether he had given much thought to it [Tollmien 1993, Wolff 2003]. The "Declaration of the Professors of the German Reich" [Erklärung der Hochschullehrer des Deutschen Reiches], dated 23 October 1914, stating tha the German army nurtured scholarship and shared its values, was however signed by over 3,100 professors, including Klein, Hilbert, Moritz Cantor, and Max Noether. The Aufruf caused great uproars abroad, the Paris Academy of Sciences voting, at the secret meetings of 15 March 1915, to exclude foreign correspondants and associates who had signed the manifesto. ${ }^{42}$

Beyond rhetorics, all over Europe and in the U.S. war was also seen as an "opportunity" for developing research, including pure research [Millikan 1919]. American scientists were most vocal about this and some examples of such wartime speeches are found in the chapter written by Archibald, Fenster, and Kent for this

\footnotetext{
${ }^{42}$ The implication of this affair for the French mathematicians' involvement in a cultural crusade against the ennemy that verged on the irrational is discussed below in Aubin, Gispert, and Goldstein's contribution to this volume.
} 
volume. In Italy and France, as various contributions to this volume show, mathematicians already held positions in the various offices for war-related research put together by Academies and governements, and French mathematicians in particular interacted with the military on a number of issues. As soon as scientific institutions were put to the service of war aims, mathematicians naturally assumed leading roles. In 1914, Paul Appell was head of the Commission of Inventions; Painlevé its secretary. As the perpetual secretary of the Academy of Sciencees, Darboux organized the self-mobilization of savants in August 1914. During the war, Picard would take his place at the Academy and use it as launchpin for rebuilding international research structures. Of a younger genaration, Borel was named director of inventions by Painlevé in November 1915. In Italy, Vito Volterra was able to follow this model quite closely as his correspondence with French mathematicians amply shows [Mazliak \& Tazzioli 2009]. In the U.K. and the U.S., by contrast, mathematicians did not seem to enjoy the same prewar prominence among scientists as they did in France or Italy. National leaders of the mobilization of science therefore came from other disciplines. In the foundation of the U.S. National Research Council, the physicist Robert Millikan and the astronomer George Ellery Hale took the leadership [Kevles 1995]. In Great Britain, their main interlocutor was the physicist Arthur Schuster. This contrasting situation was mirrored toward the end of the war in the attendees of the Inter-Allied Conferences of Scientific Academies which took place in London in October 1918 and in Paris in November 1918. Mathematicians formed the majority of the French and Italian delegates with Picard playing a crucial role as the new president of the International Research Council (IRC) [Schroeder-Gudehus 1978]. As a result, the International Mathematical Union was one of the first disciplinary bodies to emerge under the IRC and - controversially, since it was held without the participation of mathematicians coming from defeated and some neutral countries - the first to hold an international meeting in September 1920 in Strasbourg [Lehto 1998].

But the path that led to this situation had never been obvious. Among the various types of activities experienced by mathematicians in wartime, this book focuses especially on the contributions to the war effort which they were able to make as a result of their expertise, their particular training, skills, and prior experiences in the field of mathematics. One important aspect we bring to the fore is the sentiment that scientific and mathematical expertise was - at least at the beginning - misused by the military. Had scientists started earlier to play a more prominent role, many felt, precious lives would not only have been saved but also put to effective use in bringing out the innovations that were decisive in battle. This for instance was expressed by the President of the Academy of Sciences, after 18 months of fighting, on 27 December, 1915:

The nation is under attack [...]: not one [of our young savants] will miss the call. Farewell to the quiet routine of the laboratory; they are mere soldiers now; they do not even think - and it may be a pity that no one thought of this for them - to demand special posts because of their knowledge [Perrier 1915, p. 803-804; our emphasis].

Military assignments were haphazard at best and often remotely connected with prewar activities. While the historian Robert Launay became a meteorologist during the war, the mathematician Maurice Fréchet spent two and a half years as 
an interpreter with the British. The mathematics professor from Clermont-Ferrand Jules Haag believed that his superiors in the army merely saw him as a "computing machine." The case of a young Harvard Ph.D. graduate in mathematics serving as ambulance driver who wondered whether he might have been "of more use" in some other position is also dicussed below. His name was Marston Morse. ${ }^{43}$

The experience Richard Courant recounted in an interview may have been typical of the round-about ways in which several mathematicians from all countries got drafted in the technical branches of the army: "For the first two years of the war I was completely involved in strictly military service. And I was in the hospital. I had a very bad shot." Technical work, he added, came later:

I was transferred to the central research laboratory of the postal office. And I did, I built microphones. I was involved in the first electronics, first amplifiers. That was in Berlin ... But then later I was transferred - I made what the military calls an "invention" - I built some devices to listen - which later had some bearing, some importance, some relation to geophysical questions. I built something to transmit and receive signals. Not radio signals. They couldn't build such things then. But signals through the earth. It was low frequency currents for communication between the front lines and the artillery and so on. And this then mushroomed into a bigger thing, [...] then later I got completely involved in mathematics. And I did some theoretical work also, on amplifiers, tubes. [...]

So when I made this invention, I decided, I have to see that it is being used properly. I had a very interesting time. I got myself a little detachment of people, a few non-commissioned officers and technically trained soldiers, and we experimented in the front lines with this communication. I took part in the Battle of Verdun in some way. I got gassed. But I was quite interested in these matters. I became an organizer [AIP 1962].

Courant's trajectory in World War I may serve as a summary of the variety of experiences undergone by mathematicians. In the next section, we will focus on aspects of these experiences that can be said to be properly mathematical. This will however lead us to emphasize the way in which this experience helped professional mathematicians forge new forms of collaborative links with a spectrum of people, some of whom they hitherto had little chance to meet in peacetime.

\section{Mathematical Collaboration in Wartime}

As far the mathematician is concerned, he has always been in a difficult position vis-à-vis the public who does not give him credit for his results when it makes them its own and who despises them as being worthless when it does not understand them

[Busse 2008, p. 207].

\footnotetext{
${ }^{43}$ For more about Fréchet, see the contribution by Mazliak and Šišma to this volume. Launay wrote his war memoir under a pseudonym [Bréauté 1919]. Haag's case is discussed in the chapter written by Aubin. Archibald, Fenster, and Kent's contribution to this volume mentions Morse's wartime experiences.
} 
This was how Carl Runge explained, in 1915, the mathematician's predicament, as he saw it, with respect to the applications of his trade to war purposes. Indeed, mathematicians often felt it was impossible to apply the full extent of their special skills to the war effort. After he has been appointed to the Aberdeen Proving Ground to work on ballistics in 1917, the U. S. mathematician Veblen still felt that:

"there is practically nothing [related to war] that requires real mathematics. [...] I know of an important application of the problem of Apollonius (circle tangent to 3 given circles) but the real scientific interest in this is physical. I am not expecting to find any considerable math[ematica]l interest in my new department." 44

As Veblen undescored, war-related research often involved rather elementary mathematics. As a result, many people with some technical training (physicists or astronomers, engineers, artillery officers, etc.) were at least as competent as, if not better suited than, mathematicians for the tasks at hand. In other words, the successful application of mathematical techniques to war purposes required that mathematicians forge new types of collaboration with nonmathematicians in wartime.

The most obvious way in which mathematicians could as mathematicians be of immediate service was in teaching. With elementary mathematical skills now required in many combat situations, a massive number of people needed to be trained as quickly as possible, and many mathematicians were employed for this task. "The war presented an exceptional although fleeting opportunity to emphasize the fundamental necessity of mathematics in the technical equipment of the individual. [...] The student officer was required to learn and use many mathematical ideas that he had never acquired, or had frequently long forgotten" [Bennett 1919]. There was a booklet by Alexander Witting, gymnasium professor in Dresden, published in 1916 under the title Soldaten-Mathematik [Witting 1916]. It contained introductory remarks about distance measurement and interior and exterior ballistics. Likewise, mathematicians in the Allied countries often served as instructors in artillery schools. Many young French teachers were sent to the Artillery School of Fontainebleau. Lester Ford's 72-page booklet, Elementary Mathematics for Field Artillery [Ford 1919] was already mentioned: it contained sections on arithmetic, algebra, geometry, trigonometry, approximate methods, coordinates, aids to calculation, and probability, with an appendix of numerical tables. In the three months prior to the signing of the Armistice, this booklet was taught to about 15,000 students in uniform by a hundred instructors. ${ }^{45}$

When computing became a bit more complicated, interesting types of collaboration were organized between academic mathematicians and officers or military engineers. In his memoirs, Maurice d'Ocagne, the professor of geometry at the École polytechnique who was famous for having invented graphic computing methods he called nomography, explained how he was able to enroll the collaboration of practical men:

\footnotetext{
${ }^{44}$ Veblen to Birkhoff, 10 September, 1917. [Birkhoff Papers, HUG 4213.2 Box 3].

${ }^{45}$ Mathematical instruction during the war is addressed in this volume especially in the chapters by Archibald, Fenster, and Kent and by Jean-Luc Chabert and Christian Gilain.
} 
when it became imperious to adress our [materials] shortage for heavy artillery in the shortest delay, the simplicity and the swiftness of the formidable computations required by the autofrettage of the big pieces - computations that until then required the resolution of transcendant equations - was to be maximized. Nomography alone was able to overcome the difficulty, thanks in particular to the nomograms built following my method and under my supervision to meet Le Creusot [armament facilities]'s needs by the engineer L. Potin. ${ }^{46}$

Beside Louis Potin, D'Ocagne also enlisted the help of navy officer Pierre Goybet who had served in Verdun: ballistic "computations were long, hard and subject to mistakes due to the fact that they were made under the enemy's fire." 47 Thinking that nomography could help, Goybet was detached to the rear on 16 October 1916, and started to work on his firing nomograms [nomogrammes de tir] which reduced computation times from 15 to 3 minutes while eliminating most sources of errors. But d'Ocagne mostly worked with his ex-students of the École polytechique (classes of 1911 and 1913), including Jean Aubert who published a book about probability theory in wartime firing. ${ }^{48}$

Like d'Ocagne, mathematicians and scientists seized the opportunity for developing applications of their research field. Often there was no clear distinction between what was a mathematical problem or not, between the types of problems that could be addressed by theoretical or experimental means. While contrary to WWII the mathematicians' contribution to cryptology was anecdoctal, since codebreaking was mostly carried by linguists who marginally used combinatorial and statistical techniques, other mathematical problems encountered however proved more challenging for mathematicians and scientists with an advanced mathematical training. ${ }^{49}$ Some issues related to aeronautics are for example discussed in somes chapters of this volume. ${ }^{50}$ In Germany as well, aerodynamical research was especially lively: Prandtl and coworkers' famous research on the boundary layer was first published during the war in a top secret journal titled Zeitschrift der Flugzeugmeisterei [Prandtl 1918]. ${ }^{51}$ The historian Detlef Busse has claimed that

46 "lorsque s'imposa la nécessité de remédier dans le plus bref délai possible à notre pénurie d'artillerie lourde, il y eut lieu de porter au maximum la simplicité et la rapidité des formidables calculs requis par l'autofrettage des grosses pièces, calculs qui comportaient jusque là la résolution de certaines équations transcendantes. Ce fut la nomographie qui permit de venir à bout de cette difficulté, notamment grâce aux nomogrammes construits, d'après ma méthode et sous mon contrôle pour les besoins du Creusot, par l'ingénieur L. Potin" [D'Ocagne Memoirs, Book VI, p. 284].

47 "ces calculs étaient longs, pénibles, sujets à erreurs, du fait surtout qu'ils s'opéraient souvent sous le feu de l'ennemi" [D'Ocagne Memoirs, p. 285].

${ }^{48}$ Jean Aubert, La probabilité dans les tirs de guerre, préface d'Ocagne, Gauthier-Villars, Paris, 1919; Maurice d'Ocagne, Principes usuels de nomographie, avec application à divers problèmes concernant l'artillerie et l'aviation, conférences faites à la Section technique de l'artillerie (février 1919), par le lieutenant-colonel d'Ocagne, Gauthier-Villars, Paris, 1920 , 70 p. D'Ocagne's teaching at the École polytechnique is discussed in Chabert and Gilain's contribution to this volume.

${ }^{49}$ There is abundant literature on codebreaking in WWI; see for example [Kahn 1996, Lastours 1998, Collective 2001].

${ }^{50}$ Aeronautics in British contet is discussed in Barrow-Green's chapter and, in the interesting prewar context of the university of Nancy by Rollet and Nabonnand's contribution to this volume.

${ }^{51}$ On Prandtl, see [Eckert 2006]. 
Ludwig Prandtl indeed instrumentalized war to pursue his research interests in fluid mechanics, succeeding indeed in building a modern wind tunnel in Göttingen and getting army personnel to staff it [Busse 2006, Busse 2008]. Always the statesman of science, Felix Klein was instrumental in brokering the deal with the war ministry.

In the following, we shall introduce in broad terms two of the main mathematical problems for which mathematicians' expertise was relied upon in sound-ranging and exterior ballistics. Each of these problems will also be discussed in more specific terms in some of the chapters of this book.

3.1. Sound Ranging. The story of sound ranging has been told many times, but the chronology presented is often confused and the impact on mathematicians' wartime practices rarely delineated. Most accounts focus either on the technical problem of designing and selecting the proper detector for combat uses and the organizational issues related to the tactical use of sound-ranging in battle. "T2 "The chief object of Sound Ranging," explained a participant to Sound-Ranging Sections (SRS) after the war, "is to locate the position of hostile guns; it employs delicate and rather complex instruments and requires a personnel possessing a considerable degree of technical knowledge" [Hinman 1919, p. 14]. As soon as the frontline was stabilized, the practice of artillerymen underwent a tactical change whereby indirect fire became the norm. In other words, the ennemy's guns vannished from plain sight and had to be located by indirect methods. In the fall of 1914, therefore, mobilized scientists from various disciplines and military engineers spontaneously started to work on the problem of implementing sound-ranging ideas. Theoretical and experimental studies were carried out without coordination and several systems were developed concurrently. Monopolizing the question, the Army's Geographical Service (Service géographique de l'Armée), headed by General Robert Bourgeois, a polytechnician having previously specialized in geodesy, succeeded in applying the system to the field by the end of 1915 [Schiavon 2003b].

As already mentioned, many technoscientific problems raised by WWI were rather trivial in mathematical terms. The problem raised by Veblen above had arisen in the context of sound-ranging. Such problems were challenging but nevertheless accessible to anyone with good mathematical training. This question mobilized physicists as well as military and civil engineers, besides mathematicians. Although sound-ranging made it obvious that the solution to mathematical problems was needed in modern warfare, nothing special characterized the mathematicians' approach to a problem that was rather easily solved theoretically by other specialists, but that proved difficult to implement for technical, physical, and organizational reasons.

The idea of sound-ranging was simple - basically, locating the opponent's batteries by triangulating the sounds they emitted. It was its practical use on the field

\footnotetext{
${ }^{52}$ On the history of sound-ranging the literature is vast, but there is no systematic study of the various aspects in an international perspective. The story on the French and British sides is summarized in [Chasseaud 1999, p. 77-78, 96-99]. Innovation and tactical use of sound-ranging in France and Italy are discussed by Martina Schiavon: see [Schiavon 2003a, Schiavon 2003b], and her contribution to [Goldstein \& Aubin forthcoming]; see also [Thiberge 1975]; contemporary accounts of surveying in France can be found in [Bourgeois 1920] and [Arthur-Lévy 1923].
} 


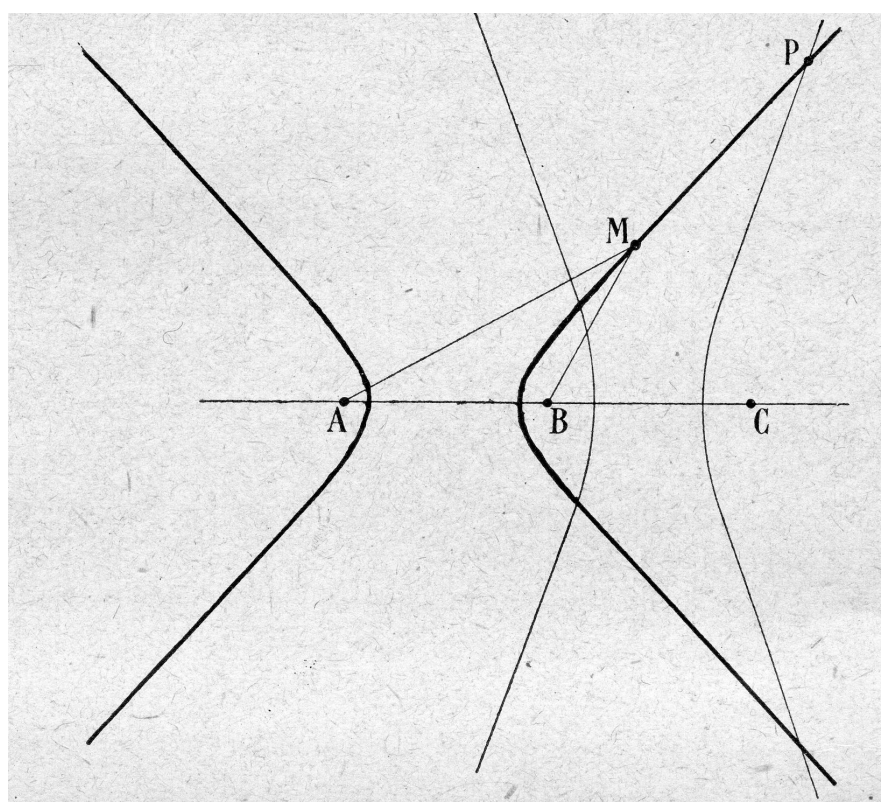

Figure 9 . The position $P$ of the enemy's battery is determined by the intersection of two hyperbolas with foci $A, B$ and $B, C$ corresponding to the observing stations [Claude 1919, p. 103].

that proved rather tricky. Be that as it may, although rather trivial, the mathematical side of the problem highlighted the way mathematical expertise could be brought to bear with military issues. At an early stage of the scientific mobilization, sound-ranging brought mathematicians and scientists to the front where they needed to discuss computing practices, the technical merits of various detectors, the physical characteristics of sound wave propagation, and the tactical use of ranging for the artillery. Occupying a great deal of people with some degree of mathematical skill, sound-ranging therefore shaped the wartime mathematical experience of scientists and combattants, as well as mathematicians' experience of war-related research. While mathematicians no doubt were greatly invested in the problem, some however felt a discrepency between their theoretical knowledge and the work that was demanded from them.

The mathematical foundation of sound-ranging was no less simple. Suppose you have three sound detectors $A, B$, and $C$ on a straight line as on figure 9 . Say the noise made by the discharge was detected first in $C$, than in $B$, and finally in $A$. The time lag between perception at $C$ and at $B, t_{c}-t_{b}$ simply means that the distance between the target $P$ and $B$ is larger than the distance between $P$ and $C$ by a fixed amount corresponding to the time lag multiplied by the speed of sound $V$, that is $V\left(t_{c}-t_{b}\right)$. But this corresponds to the definition of a hyperbola with foci $B$ and $C$. Applying the same reasoning to $A$ and $B$ led to the conclusion that the battery could be located at the intersection of two hyperbolas, defined by $P B-P A=V\left(t_{b}-t_{a}\right)$ and $P C-P B=V\left(t_{c}-t_{b}\right)$.

Alternatively, one could draw three non intersecting circles centered on $A, B$, and $C$ respectively with radii $V\left(t_{a}-T\right), V\left(t_{b}-T\right)$, and $V\left(t_{c}-T\right)$, where $T$ was a 


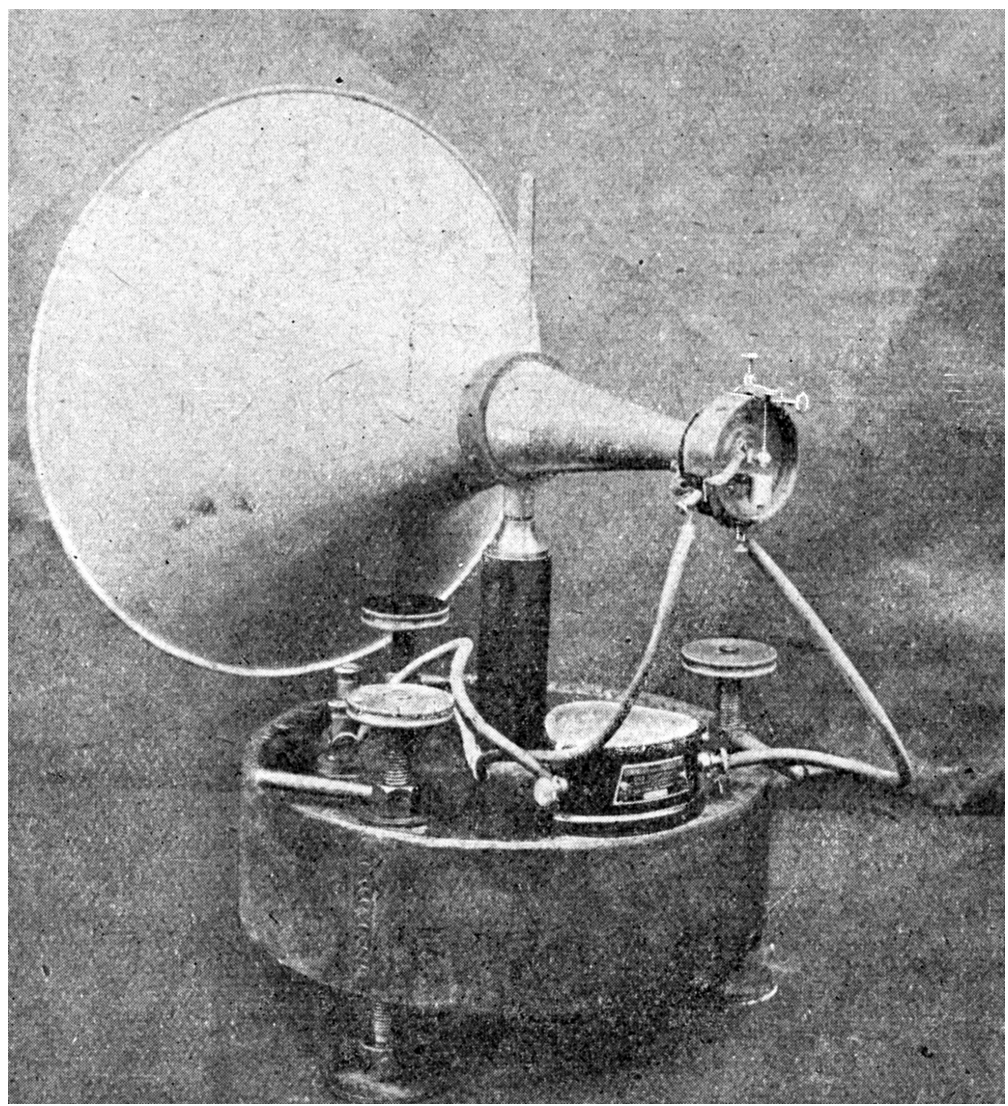

Figure 10. Georges Claude's "ruptor" sending a signal when reached by the sound wave [Claude 1919, p. 99].

conveniently chosen time. The circle tangent to the three others would be centered at the location of the enemy's gun. Interestingly, mathematicians who dealt with the problem considered the practical aspects of computation. If the three-circle method was used, "the computer may find it useful to have a set of metal disks whose radii differ successively by small amounts, the circle which touches the three circles may then be found very quickly by trial" [Bateman 1918, p. 5].

Another simplification immediately imagined was to replace the hyperbolas by their asymptotes, which worked well when the basis $A B$ was small compared to the distance to the gun. The angle $\theta$ of the asymptote to the basis could be computed easily $\cos \theta=\left(t_{b}-t_{a}\right) / t_{A B}$, where $t_{A B}$ is the time it would take for sound to travel from $A$ to $B .^{53}$

In the course of the year 1915, French scientists altogether developed four systems that took these considerations into account and that indeed seemed to work on the field. Working with Borel and Hadamard, ENS physicists Eugène Cotton and Pierre Weiss built an instrument that measured time intervals electrically.

\footnotetext{
${ }^{53}$ This is the issue debated in Lebesgue's letter to (Borel, discussed in Aubin, Gispert, and Goldstein's contribution to this volume.
} 


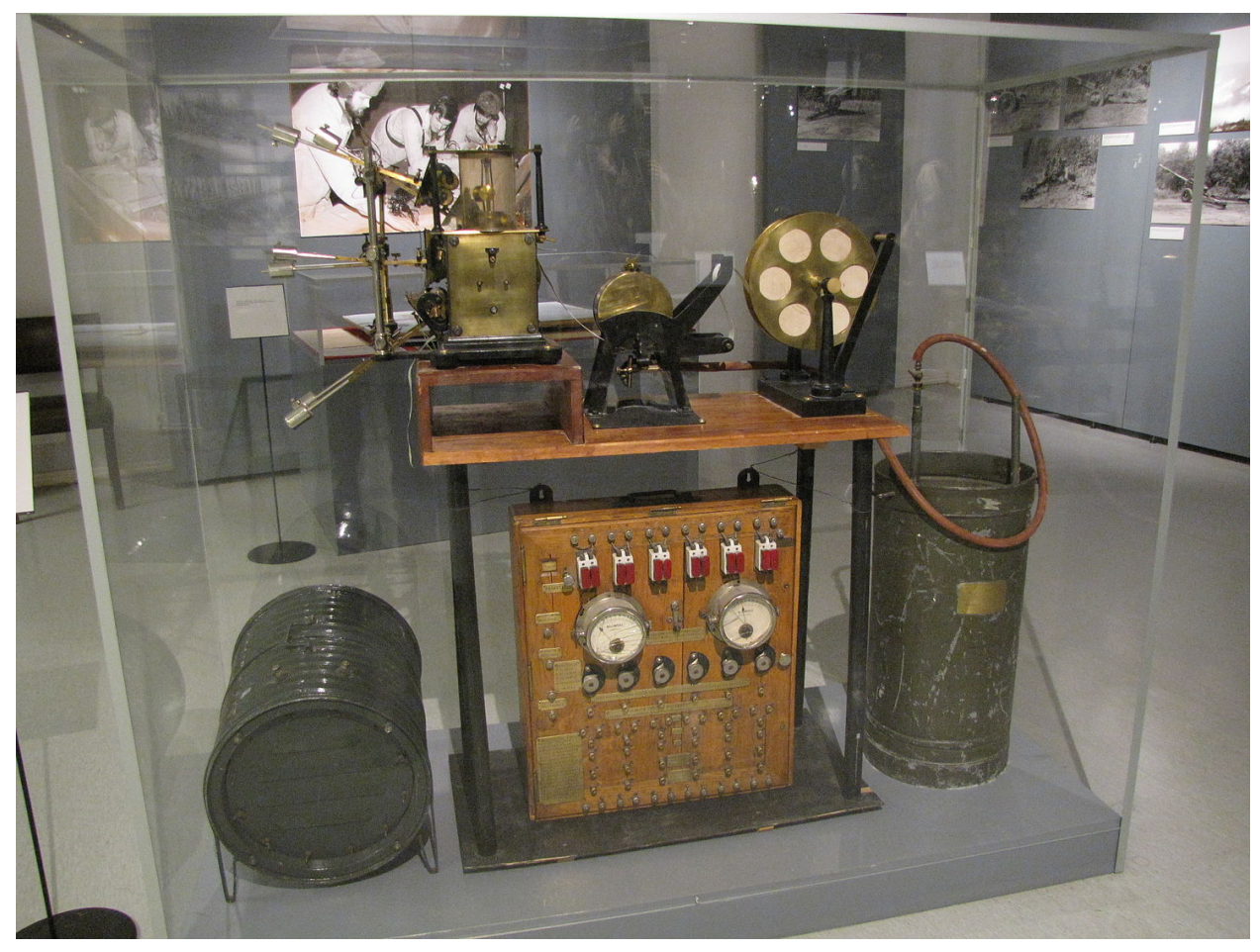

FiguRE 11. Recording unit of French artillery sound ranging system, model TM 1918. Purchased by Finland in 1927. Photographed in Hämeenlinna artillery museum.

The Cotton-Weiss system was used by the Sound Ranging Sections (SRS) commanded by Borel on the Champagne front. The second system was developed by the founder of the Liquid Air company, the physicist and industrialist Georges Claude who called his instrument the "orthophone" (fig. 10), but was frustrated in his attempts to sell it to the military [Claude 1919]. Most widely by the French army was a third system knowns as "TM 1916" (fig. 11). First developed first by the hydrogaphic engineer Ludovic Driencourt who benefited from the support of Colonel Gustave Ferrié, head of the Military Wireless Service [Télégraphie militaire] and Bourgeois' Geographical Service of the Army, it was perfected by ENS physicists Henri Abraham and Eugène Bloch [Tilho 1937, p. 199-200]. For his part, Nordmann had asked Lucien Bull, a student of the pioneer in chronophotography Étienne-Jules Maray, to design a time recording machine using microphones for which Weiss worked out the mathematical details.

Sound-ranging was quickly adopted by the Allies. Asked by the British to adapt the sound-ranging techniques to their army, the physicist and future Nobel prize recipient William L. Bragg, assisted by Lieut. Harold Robonson, who was called "an expert mathematician" even though he was a physicist from Manchester, paid a visit to Esclangon in Gâvre on 11 March 1916, before they chose Bull's apparatus. ${ }^{54}$ Esclangon recounted Bragg's visit to Gâvre. The Bull apparatus

${ }^{54}$ Quoted from "Report on Surveys on the Western Front, 1914-1918," p. 106. This report and other detailed contemporary reports by the British including international comparisons 
was later improved upon by Corporal W. S. Tucker, who had studied physics at Imperial College, London. In 1917, after a visit by French physicists Abraham and Claude Fabry, the Princeton physicist Augustus Trowbridge undertook the study of four different French systems for sound detection and also selected the Bull-Tucker system to equip the U. S. army. ${ }^{55}$

As for the German, they claimed that the idea of sound-ranging had first emerged in Austria before the war. Like the Entente armies, the German military only started to test sound-ranging procedures in the fall of 1914. The following year, the Prussian Artillery Testing commission [APK] was put in charge of developing a better protocole. The scientific direction of this project was assigned to the physicist Rudolf Walter Ladenburg, from Breslau university, assisted by Max Born, the famous physicist then privatdocent at the university of Berlin. At first, Born helped Ladenburg to work out numerical and graphical methods for sound-ranging and transform them into military regulations. Like his colleagues in the West, he developed ways to take into account wind and altitude, using Hamiltonian dynamics to study the propagation of sound. From the formulas, tables were computed by his staff (composed of students in mathematics and physics) and checked with experiments on the shooting range. "I think it was a good piece of applied mathematics" [Born 1978, p. 171]. Contrary to the Allies, Germany apparently was not able to develop the delicate measuring instruments needed for the task. Only late in the war did Born start to work on the problem posed by head waves, enrolling for this task the help of specialists in ballistics. ${ }^{56}$

As we can see and as was bluntly expressed by Lebesgue, after an initial phase of excitment, in all countries the mathematical aspects of the problem disapointed mathematicians who by and large deserted the study of sound-ranging where physicists went on to play the major part. ${ }^{57}$ But what should be noted is the fact that the adoption of effective sound-ranging methods and the constitution of soundranging sections (SRS) in the army furthered the actual use of mathematics near the trenches.

In the dozens of SRS put together by the French, British and U. S. armies, physicists and matematicians however remained the minority. Typically, six detectors, placed at know positions, detected the sound of the gun and transmitted a signal to a chronograph (figure 12). Observers and linesmen had to be positioned on or near the front line and suffered many casualties. "It must not be imagined

are available at http://www. defencesurveyors.org.uk/archives/world-war-1/ (last viewed on 3 November 2011). On British surveying more generally, see [Chasseaud 1999, Palazzo 1999, MacLeod 2000, Van der Kloot 2005].

55 [Trowbridge 1919, Compton 1937]. On American sound-ranging, see [Kevles 1969]; detailed contemporary accounts are to be found in [Hope-Jones 1928].

${ }^{56}$ Interestingly, however, sound-ranging studies in Berlin meanwhile led to the development of a strong research program in experimental psychology in order to study errors made by human observers [Hoffmann 1994].

${ }^{57}$ Let us mention the publication of a detailed article about the "mathematical theory of sound-ranging" [Bateman 1918]. A British mathematician who had emigrated to the U. S. in 1910, Harry Bateman had worked for the Weather Bureau in Washington, D.C., before being appointed at Troop College, later to become the California Institute of Technology, together with Hale and Millikan, both major actors of the American scientific mobilization. Surprisingly, this paper was published in January 1918. To be true, there was an article published earlier by Emmanual Vallier, a member of the French Commission of Inventions, who had also made public the mathematical basis of sound-ranging [Vallier 1915]. 


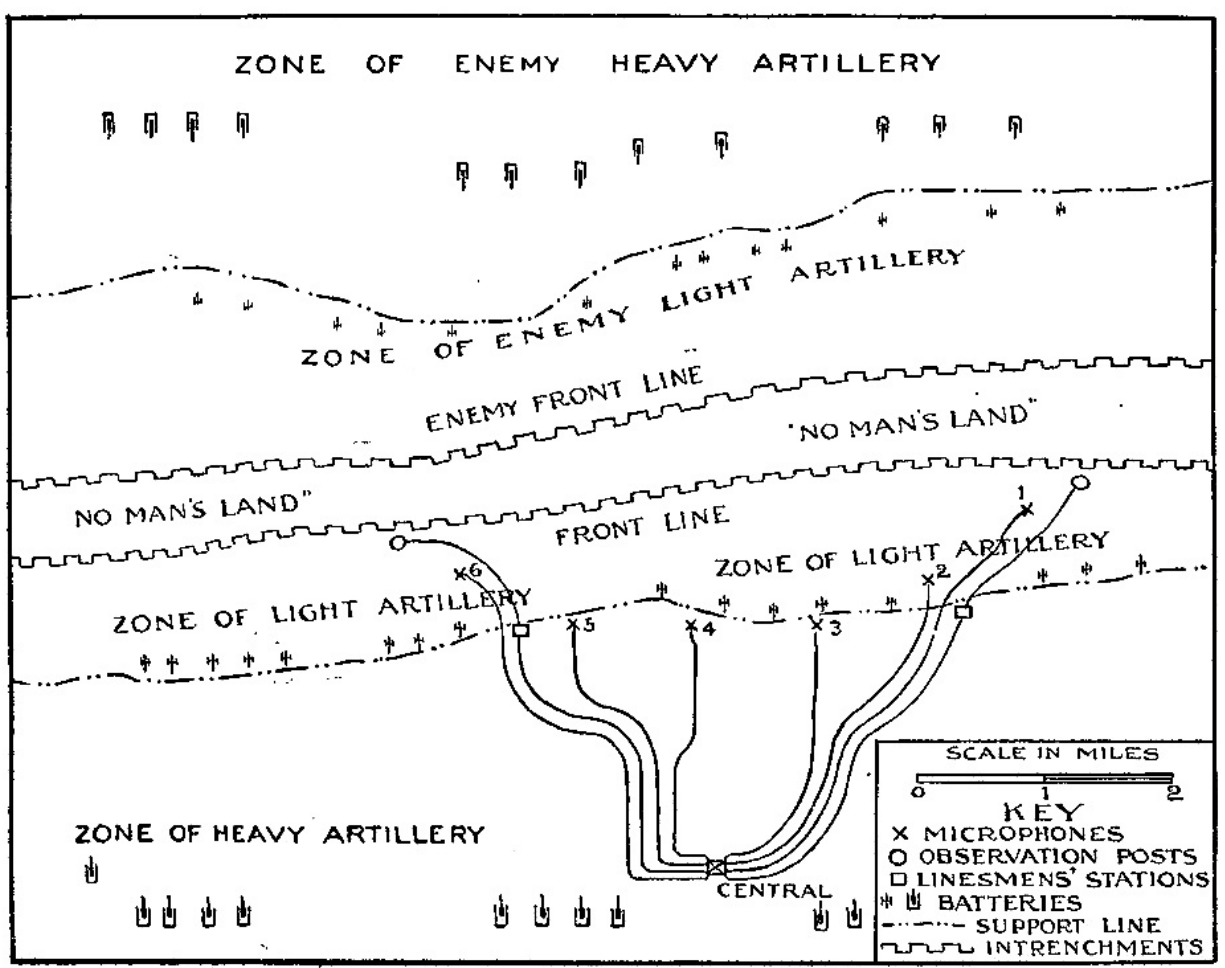

Figure 12. Diagram of a Sound-Ranging Base. Taken from

[Hinman 1919, p. 28].

that the process involved are purely mechanical; to insure the proper operation of the apparatus and to obtain information as to the calibre and direction of fire of the enemy's artillery, observers are posted well in advance of the microphones, often in the front-line trenches" [Hinman 1919, p. 14]. ${ }^{58}$ The sound ranging central station was unsually a few kilometers in the rear: "it is here that the actual data is compiled and submitted to the Chief Intelligence Officer of that section of the front. It is at the central that the greatest number of men are stationed, linesmen, computers, telephone operators and men who operate the electrical apparatus. Their work is of the utmost importance, but Mr. Censor has forbidden a detailed description of the methods used by them" [Hinman 1919, p. 48].

Time differences recorded by the detectors were reported on a board specially designed for that purpose where the intersection of strings gave the position of the piece. ${ }^{59}$ Corrections for the direction and velocity of wind and for temperature were applied. The mathematical and computation aspects of the work were, as we can see, reduced to the minimum. Indeed, if a certain level of mathematical training was recommended for sound-ranging, the British report suggested that the entire

${ }^{58}$ Other eyewitness accounts of sound-ranging on the front can be found in [Innes 1935]. There is a French novel for the youth that painted the heroic adventures of a sound-ranging section [Spitzmuller 1919].

${ }^{59} \mathrm{~A}$ paper representation of this type of boards is pictured in Aubin's contribution to this volume. 
training course for officers and computers would take no more than 17 and 14 days, respectively, to cover all practical and theoretical aspects needed to be operational on the field.

It has often been thought that sound ranging is a peculiarly difficult art, beyond the comprehension of the average man and exacting a knowledge of pure science and mathematics common only to the senior wrangler or a science master. This is absolutely erroneous. [...] Scientific control and experiment are essential but can be done behind and so long as the officers of the sections are able to understand their instruments and the value of the results they obtain it is unnecessary to specify a university degree. ${ }^{60}$

Sound ranging placed mathematics and computing at a central position in the battlefields of WWI, but the mathematics involved was never very advanced. Furthermore, every truly complex mathematical operations could be done once and for all in the rear. What was left to do for frontline practioners were the complex dayto-day maintenance of instruments and telegraphic lines under shelling. For this, "experience and coolness" [Hinman 1919, p. 14] as well as the technical knowledge required to work with delicate electrical apparatuses, were more important than mathematical aptitude.

3.2. Exterior Ballistics. In the field of exterior ballistics, by contrast to sound-ranging, mathematicians played more decisve roles. ${ }^{61}$ By 1914 , every mouthpiece came with firing tables which were supposed gave the range of its projectiles as a function of the initial angle of shooting and other variables (such as powder load and type or projectile type). Contrary to sound-ranging, ballistics was a well-established science at the start of WWI, although unevenly developed in each belligerent country. ${ }^{62}$ The dynamical equations of the ballistic problem were easy to establish, but the need to account for air resistance had plagued theoretical approaches with difficulties. Several suggestions were made for the air drag function, but theoretical ballisticians had to resign themselves to develop methods able to give approximate solutions to differential equations involving a function $f(v)$ whose exact analytical form was unknown.

$$
\begin{aligned}
g d(v \cos \theta) & =v f(v) d \theta, \\
g d x & =-v^{2} d \theta, \\
g d y & =-v^{2} \tan \theta d \theta, \\
g d s & =-v^{2} \frac{d \theta}{\cos \theta} .
\end{aligned}
$$

In these equation, $x$ and $y$ represented the Cartesian coordinates of the projectile and $s$ was the intrinsic coordinate along the path of the projectile; one also has $d x=\cos \theta d s$ and the velocity $v=d s / d t$. If integration of equation 3.1 , known as

\footnotetext{
60 "Report on Survey" (note 54), p. 41. Our emphasis.

${ }^{61}$ Ballistics in examined in greatest mathematical details in Aubin's contribution on Gâvre, but also in the chapters dealing with Great Britain, France, Italy, and the U.S. (resp. by BarrowGreen, Aubin, Gispert, and Goldstein, Nastasi and Tazzioli, and Archibald, Fenster, and Kent).

${ }^{62}$ For a history of ballistics, see [Charbonnier 1928]. As far as we know, there is no equivalent in English. See however [Gluchoff 2011].
} 


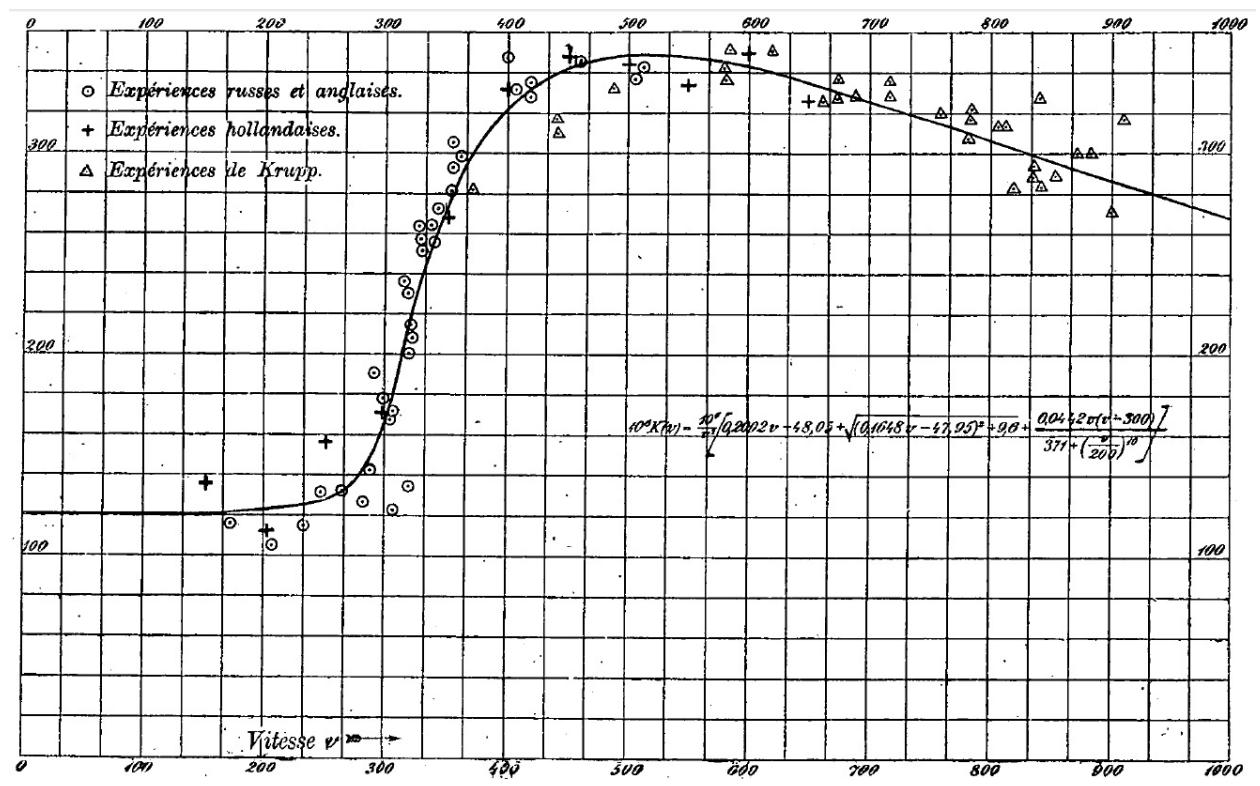

Figure 13. Air Drag as a function of the velocity. Source: [Cranz \& Vallier 1913, p. 17]. Note that the experimental data on this curve came from belligerent countries on both sides during the war and one that remained neutral: Russia, Great Britain, Holland, and from the Krupp Company, Germany.

the "hodograph," was possible, all the other quantities would be given by simple integration. But this was possible only for a limited number of special cases, none realistic enough to account for actual ballistic trajectories. By the end of the nineteenth century, the developement of practical ballistics had led to the adoption of an empirical law for air drag represented in figure 13 that clearly was nonintegrable.

At the turn of the century, rational ballistics witnessed spectacular advances, as professional ballisticians developed expeditive approximation methods enabling them to compute range tables while relying on a minimum number of costly firing tests. This was mainly due to the work of the military mathematician Francesco Siacci who taught at the School of Applied Artillery and Engineering in Turin, as well as at the university of Turin (where he was replaced by Volterra in 1893). Siacci's method was popularized, in France, by Prosper-Jules Charbonnier, a graduate of the École poytechnique who was named President of the Gâvre Commission in 1906, and in Germany by Carl Cranz, a professor at the Military Technical Academy in Berlin who was known for having introduced precise experimental procedures from physics into ballistics and produced beautiful cinematographic studies of projectiles. Meanwhile, in Great Britain, George Greenhill applied elliptic functions to integrate the hodograph in the case of cubic drag. ${ }^{63}$ Despite strong opposition, the mathematical sophistication of exterior ballistics was slowly gaining acceptance

\footnotetext{
${ }^{63}$ On Greenhill, see Barrow-Green's chapter in this volume. See also his Applications of Elliptic Functions [Greenhill 1892, p. 244]. Published in 1888, Siacci's treatise on exterior ballistics was quickly translated into French [Siacci 1892]; Charbonnier and Cranz also wrote their
} 
from artillery officers, especially in France where many officers were trained at the École polytechnique which had a strong mathematical tradition.

A practical science with its own textbooks and experimental tradition, which was - however badly - taught in military academies, exterior ballistics was in 1914 strongly pursued by military research centers in several European countries and developed into an autonomous branch of military science. But ballistics remained by and large completely foreign to civilian mathematicians and physicists. Reviewing one of Cranz's books, the historian of mathematics and high school teacher Heinrich Wieleitner wrote about ballistics:

This science, but little mentioned in the courses of mathematicians and physicists, led until recently a lively but retired life in ballistics laboratories, in the lecture halls of military academies, and on the firing ranges of weapon factories. Today, when millions of projectiles from all kinds have been fired for months, all with the purpose of reaching their target, wider circles have become interested in what are the circumstances that determine the trajectory of projectiles [Wieleitner 1915, p. 52-53].

The wide adoption of Siacci's method however had a serious drawback, namely that it worked well only for flat fire, when initial firing angles were less than 10$15^{\circ}$. But battleground conditions imposed that new tables be computed rather quickly. Before the war, it was usually assumed that artillery would be merely used as a backing for the attacks of rapidly moving infanteries and that it would fire mostly at closed range. As a consequence, there would little time for apriori computations of trajectories, which would be of little use since adjusting would easily be made de visu. As trench warfare led to the unexpected development of indirect fire, gunners came to rely more than previously on their tables. And they found them wanting. Several factors concurred to render prewar tables inadequate: the production of new, more powerful materials, especially the heavy artillery on railways, the development of anti-aircraft and mountain gunnery, the necessity to take meteorological conditions into account, etc. ${ }^{64}$ Forest R. Moulton, who was in charge of the Ballistics Branch of the Ordnance Department of the U.S. Army in April 1918, described how changes in the practice of artillery impacted theoretical and experimental ballistics:

The new demands upon artillery and the changes in artillery practice necessitated by barrage fire, counter-battery fire, longrange fire, and anti-aircraft fire, as the war progressed, raised corresponding ballistic problems. Upon entering the army a hasty examination of the classical ballistic methods showed, not only that were not well suited to the solution of the problem, even under earlier conditions. [...] Accordingly, the subject was taken up anew by the author as a scientific problem requiring close co-ordination of adequate theory and well-conducted experiments [Moulton 1926].

own textbooks, while the latter was in charge of articles about ballistics in Klein's Encyclopedia of the Mathematical Sciences [Cranz \& Vallier 1913] and [Charbonnier 1907]. For more mathematical details concerning Siacci's methods, see Aubin's chapter in this volume.

${ }^{64}$ This is discussed at some length in several contributions to this volume by Barrow-Green, by Nastasi and Tazzioli, and, especially, by Aubin. 
Soon, exterior ballistics was felt as a pressing need by military authorities who sought out technical assistance wherever it could be found. There were strong contrasts between countries, like France, where parts of the military possessed a strong mathematical culture instilled by polytechnical establishments and those, like the U. S., where since the mathematical skill of army officers was much lower mathematicians played a more active role in introducing Siacci's method and adapting them to the requirements of the Great War. "In the French field artillery there was a tradition of serious interest in guns, but in the British and German services the focus was on hauling them into action at a gallop, and then firing over open sights. Tables of logarithms were seldom consulted" [Van der Kloot 2005, p. 274] ${ }^{65}$ In Britain and Italy, contributions to this volume describe an intermediary situation. As far as Germany is concerned, it is safe to say that while Cranz played a crucial role at the Artillery Testing Commission (APK) in Berlin, many mathematicians contributed detailed studies to ballistic problems. ${ }^{66}$ Scientists and mathematicians involved in ballistics clearly produced a great number of studies that contributed to change the field in significant ways, in particular by introducing new computing procedures. Due to military secrecy, the publication of this material was tricky: "a former member of the ordnance department has told me that he has in his possession over a hundred copies, mostly unpublished blue-prints, of articles on ballistics" [Kellogg 1921, p. 543].

Like sound-ranging, therefore, practical ballistics posed problems that required other kinds of expertise. The physicist Gordon Hull from Dartmouth College put it bluntly at the end of the war:

Enough has been said to show that the fundamental problem of the projectile is not one of mathematics. There are various mathematical methods of handling the problem. [...] The problem is one of experimental science. We must first determine the complete law of air resistance for every probable form of projectile, then we must determine the variation of force as the axis of the projectile changes in direction [...]. Mathematicians may then find it necessary, using these known facts to formulate the differential equations of a twisted trajectory and to evolve methods of integration. But it is quite probable that simple physical methods of integration may be devised [Hull 1920, p. 231].

Like sound-ranging (and flight theory), ballistics involved problems for whose solution mathematical skills proved useful. For the most part, however, the needs for true mathematical innovation was scant in those fields. What was required mostly consisted in efficient methods to carry out lenghty computations and mathematical analyses of physical problems. Although, as we show in this book, mathematicians sometimes provided powerful insights in some complex problems, mathematicians for the most part proved no more useful in that task than mathematicallytrained physicists and engineers, while lagging behind in most practical matters.

\footnotetext{
${ }^{65}$ The mathematical culture of French army and navy officers is dicussed in the volume in the contribution by Aubin and by Chabert and Gilain. The ballistic situation in the U. S. is discussed in the contribution by Archibald, Fenster, and Kent to this volume. For more mathematical details on ballistics in the U. S. in the context of both military mathematics and numerical integration methods, see [Gluchoff 2011]. About computing in WWI, see [Grier 2005, ch. 9 \& 10].

${ }^{66} \mathrm{~A}$ sample of such studies among many others is: [Noether 1919, Wiener 1919].
} 
By and large, mathematicians were not the best people to address the mathematical problems raised by modern warfare.

Be that as it may, the type of mathematics involved in war-related research covered a rather wide spectrum. In this mechanical war, everything that had to do with rational mechanics was crucial. Mathematicians often had expert knowledge of this domain and its methods, but the war may have helped to distance rational mechanics from mathematical physics and theoretical physics, domains that remained nearer to mathematicians' concerns [Seth 2010]. Closely related of course were issues from mathematical analysis. The exact and approximate solutions of ordinary and partial differential equations were often required: air resistance problems led to research in conformal mapping theory and practical solution to the hodograph led to nice work in error theory from probabilistic and deterministic viewpoints. All aspects of computational mathematics were of course crucial in a war that required far more computed data than ever before. Besides the design of algorithms, the analytical treatment of errors, perturbation theory, and applications of probability theory were highly innovative.

\section{Mathematicians and mathematics through the First World War}

Besides its obvious human impact, the war allowed many men to experience mathematics differently than they might have had otherwise. For some of them this experience completely changed the course of their professional life: we will encounter many examples in what follows, including Ralph Fowler and E. A. Milne in England and Jules Haag and Maurice Fréchet in France. Bracketing the war in their resumes, as several did, was just one among several ways to deal with the return to normalcy -including in some cases the lack of understanding from a younger generation with little or no tolerance for deeply-held values sown by traumatic war experiences. A prominent member of those younger cohorts, Weil, after discussing the desastrous losses suffured by ENS students during WWI as quoted above, underlined another consequence of the war. For him, veterans were simply not carrying out very good mathematical research:

Four years or more of military life - either close to, or far from, death, but in any case far from science - are not a good preparation to come back to it; very few of those who survived recovered an interest they used to have in it. [Weil 1991, p. 132].

One of this book's aims is to show that WWI involved more effects on mathematics than the simple loss the Bourbaki thesis is ready to concede. As we have seen, many developed a lifelong, even if in some cases partial, interest in applied mathematics that was absent from their prewar research. Applied mathematics indeed received a boost from the war, and for some, as the Harvard professor Oliver Dimon Kellogg who had worked on submarine detection during the war, this showed the way of the future [Kellogg 1921, p. 543]. Many of those involved in the scientific mobilization retained part-time positions as expert or consultant for the Navy, artillery commissions, or industries. Shifting their research interests, mathematicians could also enlarge the type of professional activities they chose to engage in: from research and teaching to institutional reconstruction or political engagement. The Austrian-born mathematician Theodore Vahlen, a number-theorist before the war, worked on ballistics during the conflict and turned to applied mathematics afterwards; and he also joined the Nazi Party in 1922, becoming an ardent promoter of 
so-called deutsche Mathematik [Siegmund-Schultze 1984], that stressed visual intuition and utility against abstraction and formalism. The opposite claims made during and after the war - often much more publicized in the historiography - like Godfrey Hardy's famous dismissal of applied mathematics as trivial mathematics [Hardy1940, p. 38] — should thus be understood in the context of a much deeper involvement of mathematicians in social matters, at a large variety of scales.

In the chapters that follow, authors have aimed at capturing dynamical features of some of these changes. Focusing on individual experiences, as we have done above, allows to take the measure of chance meeting, personal relations, and previous disciplinary training. But it makes more difficult to find the articulation between the various scales at which change occured. To this end, authors have chosen to analyze transformations that happened in specific places through the war. ${ }^{67}$ While people moved from or to several places, personal war experiences were partly fossilized in such places that also went through slower modifications. Some chapters of this volume thus illustrate the effects of the war on major centers of research and teaching, like Cambridge University or the École polytechnique. Others emphasize a national level, in the United States, or in Italy, in order to reconstruct chains and shortcuts tying institutional (re)organization to personal experiences of mobilization or to specific war-related technical developements.

Although mathematicians from the Central Powers, Germany and Austria, have been prominent in our discussion above, as they were of course on the international mathematical scene before and after the war, the following chapters are restricted to (a few) Allied countries. Our discussion of the Forman thesis suggested that the result of the conflict (defeat, in the case of Germany) may blur some of the issues that emerged during the war. Face to an already extreme variety of situations, we have wished to compare as far as possible similar agendas of change. For the same reason, we have not considered here cases where radical political upheaval produced unmistakable effects on mathematics and mathematicians. In Germany, Austria, or Russia, wartime experiences were often overshadowed by political revolutions. ${ }^{68}$ The comparison between cities whose geopolitical condition shifted dramatically during and after WWI provides an excellent illustration of the complexities of mathematical (re)constructions on shifting political grounds. ${ }^{69}$

But did the Allies represented anything in mathematics? During the war, pamphlets, posters, and "days of the Allies" bear testimonies of the efforts made to reinforce the idea that the corresponding, democratic countries were united against a common ennemy. But prewar international relations in mathematics were far from overlapping nicely with political rapprochements. U.S. and Italian mathematicians, for instance, regularly traveled to Germany before the war and were greatly inspired by German mathematicians, and by Klein especially [Parshall \& Rowe 1994]. A classical opposition at the time was that between British civilization and German culture, but the opposition could function as a model to incorporate or as a foil to valorize the achievements of one's country. Some prominent British intellectuals were in the midst of a Celtic revival which made them look with a friendly curiosity

\footnotetext{
${ }^{67}$ Recently, an emphasis on places in the history of science or mathematics has been rather fruitful; this is addressed in [Aubin 2009] where reference to the literature on place can be found.

${ }^{68}$ On the Russian situation we have thus left aside here, see [Demidov 1993, Graham \& Kantor 2009]

${ }^{69}$ See Mazliak and Šišma's comparison of Strasbourg and Brno.
} 
towards their German counterparts. The French situation, on the other hand, was very different: the consequences of the 1870 war, and in particular the loss of Alsace and Lorraine, was conjugated with a enduring competition with German centers for mathematical hegemony. However, as late as the early summer 1914, German scientists visited Gustave Eiffel's aerodynamical laboratory [Fontanon 1998].

As will appear at several points in this book, wartime alliances indeed led to Inter-Allied scientific collaboration: innovations in firing tables were shared; observation trips in the respective Allied proving grounds organized; institutional models copied. After the war, the circulation of mathematics still matched these alliancesat least during the early 1920s. Renewed arguments in favor of the universality of science and mathematics clashed head-on, starting in 1918, with the hope that a new internationalism could grow out of Allied nations by excluding mathematicians from former the Central Powers. In the mid-twenties and thirties, the Rockefeller foundation would play a decisive role to construct afresh, if not internationalism per $s e$, at least a large circulation of young mathematicians among nations including former Central Powers [Siegmund-Schultze 2001]. But even internationalism restricted to the Allies at the end of First World War was no guarantee of a unity of objectives. ${ }^{70}$ Two nationals of Belgium, a formerly neutral nation that had taken side with the Allies after German troops invaded its territory, might serve as an illustration. While the mathematician Charles de la Vallée-Poussin declared in 1924 that "the mathematical sciences [...] often borrow from the French mind a definite orientation" [SMF 1924, p. 35], the historian of sciences Georges Sarton who had taken refuge in the U.S. expressed his "faith in the Anglo-Saxon conception of life, and also [his] love of and [his] hope in the younger civilizations of the world" [Sarton 1919, p. 321].

We have chosen in the first four chapters to draw comparisons by following the chronology of the war. We first discuss two important places for mathematics, Cambridge and Paris, and their very different experience of early mobilization. We then turn to universities in Italy and the States, as the delayed entrance of their country into the war, in 1916 and 1917 respectively, allows us to take stock of the debates among mathematicians on the opportunity to join in or not, and of the mathematical links the war fostered. We then move to studies, at a smaller scale, of the fate of two places where collaboration between mathematicians and the military preceded the war, and still was changed by it, the École polytechnique and the Gâvre commission. In the last two chapters, we analyze two effects of the redistribution of territory and frontiers in the middle of Europe. We contrast the case of Nancy, which was before 1919 a bridgehead for French mathematics at the limit of the then German Lorraine, and a pioneering center for applied mathematics and receded in the interwar period, and of Brno, where the mathematicians of the newly created Czechoslovakia successfully reorganized their research trends and alliances. ${ }^{71}$

Several common phenomena can be exhibited among the cases surveyed here. In most, the postwar period was for instance a time of intense institutional reconstruction (sometimes forced by the material destruction of older buildings, as in

\footnotetext{
${ }^{70}$ On this issue, also see [Siegmund-Schultze 2001, ch. 1].

${ }^{71}$ For the differences and the similarities with Poland and the creation of Fundamenta Mathematicae in 1920, see [Duda 1996].
} 
Lille) supported by the wish to draw lessons from the war. Chairs of fluid mechanics, to take but one example, were created almost simultaneoulsy in several countries - sometimes inside new institutes, sometimes in more traditional university settings. This in turn led to an academic disciplinarization (via new textbooks and new curricula) of certain topics which were before the war either a simple collection of results issued from various mathematical fields or left to professionals outside academia. More generally, networks that were sometimes created haphazardly in wartime through chance encounters or personal connections were transformed into officially funded commissions or institutions. Pure mathematics was also affected in several ways: as seen above, it was for some a refuge and a worthwhile escape from postwar discourses and activities. But the war also left new epistemological marks. For instance, the way in which computing issues were brought to the fore not only paved the way to the future developement of the computing machines and of proper institutes, but also led some mathematicians to reconsider their theoretical work in this light. A delayed eloge of Châtelet's number-theoretical Peccot lectures at the Collège de France delivered just before the outbreak of the WWI claimed for instance that Châtelet had "revealed [...] the use and the efficacy of these algorithms, the use of which has since become constant in theoretical physics and in mathematics applied to industrial technology." 72

This leads us to examine afresh the question of modernity and modernization in mathematics. In his pioneering work [Mehrtens 1990, Mehrtens 1996b], the historian Herbert Mehrtens distinguished within the process of modernity, a modernist trend (the only one usually associated with the expression "modern mathematics" from a countermodernist one. For him, important characteristics of modern mathematics were "first, the autonomy of cultural production and, second, the departure from the vision of an immediate representation of the world of experience. [...] Modern axiomatic, conceptual, and structural mathematics becomes largely anti-intuitive. It is the mathematics of autonomous professionals" [Mehrtens 1996b, p. 521]. In this view, professional mathematicians also postioned themselves as internationalists who were opposed to national or cultural biases. Countermodernists, on the contrary, would stress intuition and an externalist basis for the truth and meaning of mathematics, whether in the natural sciences or in society. Moreover, modernists have mostly been identified with an avantgarde developing pure mathematics. "Mathematicians of a more conservative type or mathematicians in applications, hybrid fields or in teaching cannot fully identify with the modernist attitude" [Mehrtens 1996b, p. 523]. Severing mathematics from sciences and society is an important part of the dichotomy [Epple1999, p. 193]. Confronted with ideals of modernization and rationalization put forward by the Rockefeller philanthropists, Reinhard Siegmund-Schultze, undescored the difficulties of equating a modernist position in pure mathematics, as defined above, and simple progress or innovation.

The studies that follow show how the war indeed redistributed these frontiers. Whether they integrated or not some of the internal values of modern mathematics, the point is that many mathematicians of the war generation extended the limits of their profession beyond academic research. Some simply juxtaposed activities of various kinds (most of which being neglected by the historiography), while others, in particular in France, claimed that holding together and knitting all these aspects,

\footnotetext{
${ }^{72}$ Quoted in Gauthier's contribution to [Goldstein \& Aubin forthcoming].
} 
from the most theoretical and general theorems in, say, differential equations, to the construction of a center of computations in close contact with industry, was the essential mission of the future, adequately modern, mathematician. These activities of the interwar period certainly required more investigation. But in this respect, the Bourbaki thesis already appears less as a complete, objective, description of the war effect than a consequence of the position of its promotors inside mathematics, and of their choice as to what a mathematical life is made of. Paradoxically enough, their vision widened the gap created the war experience, while the spokepersons of the war generation (as witnessed above in Châtelet's case) often strove to reconnect beyond the war the threads of their profesional lifes torn apart by four years of massive destruction.

\section{List of abbreviations.}

- APK: Artillerie-Prüfungs-Kommission

- CRAS: Comptes rendus des séances hebdomadaires de l'Académie des sciences.

- ENS: École normale supérieure, Paris.

- ICMI: International Commission on Mathematical Instruction.

- IRC: International Research Council.

\section{Bibliography}

[Birkhoff Papers] George David Birkhoff Papers, Harvard University Archives.

[Borel Papers] Fonds Émile Borel, Archives of the Academy of Sciences, Paris, 44J.

[D'Ocagne Memoirs] Maurice d'Ocagne, Souvenirs de Maurice d'Ocagne, membre de l'Académie des Sciences, 1862-1938. Manuscript at the Bibliothèque de l'Institut de France, Quai Conti, Paris, Ms. 4671-4674, n.d.

\section{Published Works}

[AASAE] Association amicale de secours des anciens élèves de l'École normale supérieure, Réunion générale annuelle, volume annuel, 1915-2009.

[AIP 1962] Interview with Richard Courant, by Thomas S. Kuhn \& Mark Kac, on 9 May 1962, Niels Bohr Library \& Archives, American Institute of Physics, College Park, MD USA, www . aip.org/history/ohilist/4562.html.

[Andler 1994] Martin Andler, Les mathématiques à l'École normale supérieure, in L'École normale supérieure : le livre du bicentenaire, dir. Jean-François Sirinelli, Presses universitaires de France, Paris, 1994, p. 351-404.

[Anizan 2006] Anne-Laure Anizan, Paul Painlevé (1863-1933): un scientifique en politique, doctoral thesis, Institut d'études politiques, Paris, 2006.

[Anonymous 1906] Anonymous, La généralisation d'un théorème de Lagrange, Revue du mois 2 (1906), p. 508-510.

[Arthur-Lévy 1923] Arthur-Lévy, Les coulisses de la guerre : le service géographique de l'armée (1914-1918), Revue des deux mondes 17 (1923), p. 419-452.

[Aubin 1997] David Aubin, The Withering Immortality of Nicolas Bourbaki: A Cultural Connector at the Confluence of Mathematics, Structuralism and the Oulipo in France, Science in Context 10 (1997), 297-342.

[Aubin 2005] David Aubin, George David Birkhoff, Dynamical Systems (1927), In Landmark Writings in Western Mathematics, 1640-1940, ed. Ivor Grattan-Guinness, Elsevier, Amsterdam, 2005, p. 871-881.

[Aubin 2009] David Aubin, Observatory Mathematics in the Nineteenth Century, in Oxford Handbook for the History of Mathematics, ed. Eleanor Robson \& Jacqueline Stedall, Oxford University Press, Oxford, p. 273-298.

[Aubin, in preparation] David Aubin, L'Élite sous la mitraille : mémoire et oubli de la Grande Guerre chez les mathématiciens de l'École normale supérieure, to appear. 
[Aubin \& Bret 2003] , David Aubin et Patrice Bret, eds., Le Sabre et l'éprouvette: l'invention d'une science de guerre, 1914-1939, 14-18 Aujourd'hui, Agnès Viénot, Paris, 2003.

[Audin 2009] Michèle Audin, Fatou, Julia, Montel : Le Grand Prix des sciences mathématiques de 1918, et après..., Springer, Berlin, 2009.

[Audin 2010] Michèle Audin, review of Reinhard Siegmund-Schultze, Mathematicians Fleeing from Nazi Germany: Individual Fates and Global Impact (Princeton, 2010), Notices of the American Mathematical Society 57 (2010), p. 1300-1302.

[Audoin-Rouzeau \& Becker 2000] Stéphane Audoin-Rouzeau et Annette Becker, 14-18. Retrouver la guerre, Gallimard, Paris, 2000.

[Barolet 1916] Henri Barolet, Question d'analyse indéterminée, L'Enseignement mathématique 18 (1916), p. 269-272.

[Bateman 1918] Harry Bateman, Mathematical Theory of Sound Ranging, Monthly Weather Review 46 (1918), p. 4-11.

[Beaulieu 1993] Liliane Beaulieu, A Parisian Café and Ten Proto-Bourbaki Meetings (19341935), The Mathematical Intelligencer, 15(1) (1993), 27-35.

[Beaulieu 1994] Liliane Beaulieu, Questions and Answers about Bourbaki's Early Work (19341944), in The Intersection of History and Mathematics, ed. Sasaki Chikara et al., Birkhäuser, Basel, 1994, p. 241-252.

[Beaulieu 2009] Liliane Beaulieu, Regards sur les mathématiques françaises entre les deux guerres, Revue d'histoire des sciences 62-1 (2009), p. 9-37.

[Bell 1915] Clive Bell, Art and War, International Journal of Ethics 26 (1915), p. 1-10.

[Bennett 1919] Albert A. Bennett, Review of Ford's Elementary Mathematics for Field Artillery, The American Mathematical Monthly 26 (1919), p. 353-355.

[Berger 2005] Marcel Berger, Cinq siècles de mathématiques en France, Association pour la diffusion de la pensée française \& Ministère des affaires étrangères, Paris, 2005.

[Berndt \& Rankin 1995] Bruce C. Berndt \& Robert A. Rankin, Ramanujan: Letters and Commentaries, AMS/LMS, Providence \& London, 1995.

[Bliss 1944] Gilbert A. Bliss, Oskar Bolza - In memoriam, Bulletin of the American Mathematical Society 50 (1944), p. 478-489.

[Born 1918] Max Born, Herbert Herkner, Die Naturwissenschaften 6 (1918), p. 179-180.

[Born 1978] Max Born, My Life: Recollections of a Nobel Laureate, Taylor \& Francios, London, 1978.

[Bourbaki 1960] Nicolas Bourbaki, Éléments d'hisoire des mathématiques, Hermann, Paris, 1960.

[Bourgeois 1920] Robert Bourgeois, Le Service géographique de l'Armée pendant la guerre, Revue scientifique $\mathbf{5 8}$ (1920), p. 673-685.

[Bréauté 1919] Roland Bréauté [Robert Launay], Un universitaire aux Armées, Brossard, Paris, 1919.

[Burgess 1919] George K. Burgess, Science and the After-War Period, Scientific Monthly 8 (1919), 97-108.

[Busse 2006] Detlef Busse, Forschung im Krieg - Forschung durch den Krieg: von der Instrumentalisierung militärischer Interessen für die Errichtung der Göttinger Modellversuchtanstalt, Kollegen - Kommilitonen - Kämpfer: Europäische Universitäten im Ersten Weltkrieg, ed. Trude Maurer, Franz Steiner Verlag, Munich, 2006, p. 283-296.

[Busse 2008] Detlef Busse, Engagement oder Rückzug? Göttinger Naturwissenschaften im Ersten Weltkrieg, Schriften zur Göttinger Universitätsgeschichte 1, Universitätsverlag, Göttingen, 2008.

[Butzer et al. 1984] P. L. Butzer, R. J. Nessel, and E. L. Stark, Eduard Helly (1884-1943), in memoriam, Results in Mathematics 7 (1984), 145-153.

[Butzer et al. 1980] P. L. Butzer, S. Gieseler,F. Kaufmann, R. J. Nessel, and E. L. Stark, Eduard Helly (1884-1943), Jahresbericht der Deutschen Mathematiker-Vereinigung 82 (1980), 128 151.

[Charbonnier 1907] Prosper-Jules Charbonnier, Balistique extérieure rationnelle, O. Douin, Paris, 1907.

[Charbonnier 1928] Prosper-Jules Charbonnier, Essais sur l'histoire de la balistique, Société d'éditions géographiques, maritimes et coloniales, Paris, 1928.

[Chasseaud 1999] Peter Chasseaud, Artillery's Astrologers: A History of British Survey and Mapping on the Western Front, 1914-18, Mapbooks, Lewes, 1999. 
[Clairin 1920] Jean Clairin, Sur les invariants des caractéristiques des équations aux dérivées partielles à deux variables indépendantes, ed. by Émile Gau, Ann. Sci. E.N.S. 37 (1920), $107-116$.

[Claude 1919] Georges Claude, Politiciens et polytechniciens: Au creuset de la guerre, private ed., Boulogne-sur-Seine, 1919.

[Collective 1916] Friends of France: The Field Service of the American Ambulance Described by its Members, Houghton-Mifflin Company, Boston \& The Riverside Press, Cambridge, 1916.

[Collective 1918] Noranze a Luciao Orlando, Rugiero Torelli, Eugenio Elia Levi, Adolfo Viterbi, professori di matematica nelle università italiane, caduti in guerra, Seminario matematico della facoltà di scienze della R. università di Roma, 1918.

[Collective 2001] Le chiffre, le renseignement et la guerre : actes du colloque de l'Historial de la Grande Guerre de Péronne, du 21 et 22 mars 2001, L'Harmattan, Paris, 2001.

[Compton 1937] Karl L. Compton, Augustus Trowbridge, 1870-1934, Biographical Memoirs of the National Academy of Sciences 18 (1937), p. 219-244.

[Coray et al. 2003] Daniel Coray, Fulvia Furinghetti, Hélène Gispert, Brian H. Hodgson, Gert Schubring, eds., One Hundred Years of L'Enseignement Mathématique. Moments of Mathematics Education in the Twentieth Century. Proceedings of the EM-ICMI Symposium Geneva, 20-22 October 2000, L'Enseignement Mathématique, Geneva, 2003.

[Cranz \& Vallier 1913] Carl Cranz and Emmanuel Vallier, Ballistique extérieure, in Encyclopédie des sciences mathématiques pures et appliquées, ed. Jules Molk and Paul Appell, tome IV, $6^{\mathrm{e}}$ volume, $1^{\mathrm{er}}$ fascicule, Gauthier-Villars, Paris \& H. G. Teubner, Leipzig, 1913.

[D 1915] D. La guerre en formules, Bulletin technique de la Suisse romande 41 (1915), p. 9-10.

[Dauben 1980] Mathematicians and World War I: The International Diplomacy of G. H. Hardy and Gosta Mittag-Leffler as Reflected in their Personal Correspondence, Historia mathematica 7 (1980), p. 261-288.

[Daudet 1918] Léon Daudet, La Guerre totale, Nouvelle librairie nationale, 1918.

[Delsarte 1944] Jean Delsarte, Rapport général du Groupe d'études préparatoires en vue d'une meilleure orientation des étudiants vers la recherche scientifique, Centre de Documentation universitaire Tournier et Constans, Paris, 1944; repr. in Euvres, vol. 2, CNRS, Paris, 1971, p. $973-1050$.

[Deltheil 1917] Robert Deltheil, F. Lebeau, Association amicale de secours des anciens élèves de l’École normale supérieure (Paris), Réunion générale annuelle (1917), p. 130-133.

[Demidov 1993] Sergei Demidov, La revue Matematicheskii Sbornik dans les années 1866-1935 in Messengers of Mathematics, ed. E. Ausejo, M. Hormigon, Siglo XXI de Espana Editores, Madrid, 1993, p. 235-256.

[Dieudonné 1969] Jean Dieudonné, Regards sur Bourbaki, Analele universitatii Bucaresti, Matematica-mecanica 18 (1969), p. 13-25.

[Dieudonné 1970] Jean Dieudonné, The Work of Nicolas Bourbaki, American Mathematical Monthly, 77 (1970), p. 134-145.

[Duda 1996] Roman Duda, Fundamenta Mathematicae and the Warsaw School of Mathematics in L'Europe mathématique. Mathematical Europe, ed. C. Goldstein, J. Gray, J. Ritter, MSH, Paris, 1996, p. 479-498.

[Dugac 1995] Pierre Dugac, Jean Dieudonné : mathématicien complet, Jacques Gabay, Paris, 1995.

[Eddington 1917] Arthur S. Eddington, Karl Schwarzschild, Monthly Notices of the Royal Astronomical Society $\mathbf{7 7}$ (1917), p. 314-319.

[Eckert 2006] Michael Eckert, The Dawn of Fluid Dynamics: A Discipline between Science and Engineering, Wiley-VCH, Berlin/Weinheim, 2006.

[Epple1999] Mortiz Epple, Die Enstehung der Knotentheorie. Kontexte und Konstructionen einer modernen mathematischen Theorie, Vieweg, Braunschweig and Wiesbaden, 1999.

[Feferman \& Feferman 2004] Anita Burdman Feferman \& Solomon Feferman, Alfred Tarski: Life and Logic, Cambridge University Press, Cambridge, 2004.

[Fontanon 1998] Claudine Fontanon, ed., Enseignement, recherche et pratiques mécaniques en France après 1880, Cahiers d'histoire et de philosophie des sciences 46, SFHST-ENS Éditions, Paris, 1998.

[Fontanon \& Franck 2005] Claudine Fontanon and Robert Franck, Paul Painlevé, 1863-1933: un savant en politique, Presses universitaires de Rennes, Rennes, 2005. 
[Ford 1918] Lester R. Ford, Rational Approximations to an Irrational Complex Number, Transactions of the American Mathematical Society 19 (1918), p. 1-42.

[Ford 1919] Lester R. Ford, Elementary Mathematics for Field Artillery, prepared and published by direction of the Chief of Field Artillery, Field Artillery Central Officers' Training School, Camp Zachary Taylor, Kentucky (Instruction Memo. No. 20), Courier Journal Press, Louisville, Kentucky, 1919.

[Forman 1971] Paul Forman, Weimar Culture, Causality, and Quantum Theory, 1918-1927: Adaptation by German Physicists and Mathematicians to a Hostile Intellectual Environment, Historical Studies in the Physical Sciences 3 (1971), 1-115.

[Forman 1973] Paul Forman, Scientific Internationalism and the Weimar Physicists: The Ideology and Its Manipulation in Germany after World War I, Isis 64 (1973), 151-180.

[Forman 1974] Paul Forman, The Financial Support and Political Alignment of Physicists in Weimar Germany, Minerva 12(1974), 39-66.

[Friedman 1982] Robert M. Friedman, Constituting the Polar Front, Isis 73 (1982), 343-362.

[Galvez-Behar 2008] Gabriel Galvez-Behar, La République des inventeurs: propriété et organisation de l'innovation en France (1791-1922), Presses universitaires de Rennes, Rennes, 2008.

[Gispert 1991] Hélène Gispert, La France mathématique: La Société mathématique de France (1870-1914), Société française d'histoire des sciences et des techniques; Société mathématique de France, Paris, "Cahiers d'histoire et de philosophie des sciences," 34.

[Gispert \& Leloup 2009] Hélène Gispert \& Juliette Leloup, Des patrons des mathématiques en France dans l'entre-deux-guerres, Revue d'histoire des sciences 62, 39-118.

[Gladden 1930] E. N. Gladden, At Messines Ridge in 1917, in Everyman at War, ed. Charles B. Purdom, J. M. Dent, London, 1930, p. 114-121.

[Gluchoff 2011] Alan Gluchoff, Artillerymen and mathematicians: Forest Ray Moulton and changes in American exterior ballistics, 1885-1934, Historia Mathematica 38 (2011), p. 506547.

[Goldstein 2009] Catherine Goldstein, La théorie des nombres en France dans l'entre-deuxguerres : de quelques effets de la première guerre mondiale, Revue d'histoire des sciences 62-1 (2009), p. 143-175.

[Goldstein et al. 1996] Catherine Goldstein, Jeremy Gray \& Jim Ritter, L'Europe mathématique : mythes, histoires, identités, Maison des Sciences de l'Homme, Paris, 1996.

[Goldstein \& Aubin forthcoming] Catherine Goldstein \& David Aubin, eds., La Grande Guerre des mathématiciens français +++

[Goursat 1916] Edouard Goursat, Jean Clairin, Bulletin de la Société mathématique de France 44 (1916), 15-16.

[Goursat 1925] Édouard Goursat, Le problème de Bäcklund, Mémorial des sciences mathématiques 6, Gauthier-Villars, Paris, 1925.

[Graham \& Kantor 2009] Loren Graham \& Jean-Michel Kantor, Naming Infinity: A True Story of Religious Mysticism and Mathematical Creativity, Harvard University Press, Cambridge, 2009.

[Grattan-Guinness 1972] Ivor Grattan-Guinness, A Mathematical Union: William Henry and Grace Chisholm Young, Annals of Science 29 (1972), p. 105-186.

[Greenhill 1892] George Greenhill, Applications of Elliptic Functions, Macmillan, New York, 1892.

[Grier 2005] David Alan Grier, When Computers Were Human, Princeton University Press, Princeton, 2005.

[Guillaume 1994] Marcel Guillaume, La logique mathématique en sa jeunesse, in [Pier 1994], p. $185-367$.

[Hadamard 1916] Jacques Hadamard, Lery (Georges), né à Limours le 28 avril 1880, tué à l'ennemi le 10 septembre 1914. - Promotion de 1899, in Association amicale de secours des anciens élèves de l'École normale supérieure (Paris), 1916, p. 112-116.

[Hadamard 1920] Jacques Hadamard, Rapport sur les travaix examinés et retenus par la Commission de Balistique pendant la durée de la guerre, CRAS 170 (1920), p. 435-445.

[Hale 1919] George Ellery Hale, The Responsibilities of the Scientist, Science 50 (1919), p. 143146.

[Hanna 1996] Martha Hanna The Mobilization of Intellect: French Scholars and Writers during the Great War, Harvard, Cambridge, Mass., 1996. 
[Hardy1940] Godfrey H. Hardy, A Mathematician's Apology, Cambridge University Press, Cambridge, 1940. Reprinted with Foreword by C. P. Snow, 1967.

[Hardy 1943] Godfrey H. Hardy, William Henry Young 1863-1942, Obituary Notices of the Fellows of the Royal Society 4 (1943), p. 307-323.

[Hartcup 1988] Guy Hartcup, The War of Invention: Scientific Development, 1914-18, Brassey's Defence Publ., London, 1988.

[Heath 1921] Thomas Heath, A History of Greek Mathematics, Clarendon Press, Oxford, 1921.

[Hilbert 1917] David Hilbert, Axiomatisches Denken, Mathematische Annalen 78 (1917), p. 405415.

[Hinman 1919] Jesse R. Hinman, Ranging in France with Flash and Sound, Press of Dunham Printing Company, Portland, Oregon, 1919.

[Hoffmann 1994] Christoph Hoffmann, Wissenschaft und Militär: Das Berliner Psychologieche Institut und der I. Weltkrieg, Psychologie und Geschichte 5(1994), p. 261-285.

[Hope-Jones 1928] W. Hope-Jones, Sound-Ranging, The Mathematical Gazette 14 (1928), p. $173-186$.

[Horne 2005] John Horne, Entre expérience et mémoire: les soldats français de la Grande Guerre, Annales: histoire, sciences sociales 60, p. 903-919.

[Hottin 2000] Christian Hottin, 80 ans de la vie d'un monument aux morts, Labyrinthe 5 (2000), [online: url: http://labyrinthe.revues.org/index262.html. Last viewed November 2, 2009. ]

[Houzel 2004] Christian Houzel, Le rôle de Bourbaki dans les mathématiques du vingtième siècle, Gazette des Mathématiciens 100 (2004), 52-63.

[Hughes 1977] Thomas P. Hughes, Elmer Sperry: Inventor and Engineer, Johns Hopkins Univ. Press, Baltimore, 1977.

[Hull 1920] Gordon F. Hull, Some Aspects of Physics in War and Peace, Science 51 (1920), p. 221-233.

[Hull 1991] Andrew Hull, War of Words: The Public Science of the British Scientific Community and the Origins of the Department of Scientific and Industrial Research, 1914-16, British Journal for the History of Science 32 (1991), 461-482.

[Innes 1935] J. R. Innes, ed., Flash Spotters and Sound Rangers: How They Lived, Worked, and Fought in the Great War, George Allen \& Unwin Ltd, London, 1935.

[Jay 2005] Martin Jay, Songs of Experience: Modern American and European Variations on a Universal Theme, University of California Press, 2005.

[Johnson 1990] Jeffrey Allan Johnson, The Kaiser's Chemists: Science and Modernization in Imperial Germany, Univ. of North Carolina Press, Chapel Hill, 1990.

[Julia 1919] Gaston Julian [sic], Lambert (Paul-Jean-Étienne), né à Annecy le 27 février 1894, tué à l'ennemi près de Fontenoy (Aisne) le 15 mars 1915. - Promotion de 1911, Association amicale de secours des anciens élèves de l'École normale supérieure (Paris), 1919, p. 109-113.

[Kahn 1996] David Kahn, The Codebreakers, rev. ed., Scribner, New York, 1996.

[Kamke \& Zeller 1957] E. Kamke \& K. Zeller, Konrad Knopp, Jahresbericht der Deutschen Mathematiker-Vereinigung 60 (1957), p. 43-49.

[Kellogg 1921] Oliver Dimon Kellogg, A Decade of American Mathematics, Science 53 (1921), p. $541-548$.

[Kevles 1969] Daniel Kevles, Flash and Sound in the A[merican] E[xpeditory] F[orce]: The History of a Technical Service, Military Affairs 33 (1969), p. 374-384.

[Kevles 1995] Daniel Kevles, The Physicists: The History of a Scientific Community in Modern America, 2nd ed., Harvard Univ. Press, Cambridge, Mass., 1995.

[Klein 1934] Jacob Klein, Die griechische Logistik und die Entstehung der Algebra, Quellen und Studien zur Geschichte der Mathematik, Astronomie und Physik, Abteilung B: Studien 3, no. 1 (1934), p. 18-105; no. 2 (1936), p. 122-235. English transl.: Greek Mathematical Thought and the Origin of Algebra, Cambridge, Mass.: M.I.T. Press, 1969.

[Kreyszig 1992] Erwin Kreyszig, Remarks on the Mathematical Work of Tibor Radó, in [Rassias 1992], p. 18-32.

[Lamb 1974] George L. Lamb, Bäcklund transformations for certain nonlinear evolution equations, Journal of Mathematical Physics 15 (1974), p. 2157-2165.

[Lamb 1976] George L. Lamb, Bäcklung Transformations at the Turn of the Century, Bäcklund Transformations, the Inverse Scattering Method, Solitons, and Their Applications, Lecture Notes in Mathematics 515, Springer, Berlin, 1976, p.69-79. 
[Lastours 1998] Sophie de Lastours, La France gagne la guerre des codes secrets, Tallandier, Paris, 1998.

[Lebesgue 1991] Lettres d'Henri Lebesgue à Émile Borel, Cahiers du séminaire d'histoire des mathématiques 12 (1991), 1-506.

[Lehto 1998] Olli Lehto, Mathematics Without Borders: A History of the International Mathematical Union, Springer, New York, 1998.

[Leloup 2009] Juliette Leloup, L'entre-deux-guerres mathématique, à travers les thèses soutenues en France, doctoral thesis, Université Pierre et Marie Curie, Paris, 2009, http://www.math.jussieu.fr/ leloup/These_Leloup_Juliette.pdf.

[Lepick 1998] Olivier Lepick, La Grande Guerre chimique, 1814-1918, Presses universitaires de France, Paris, 1998.

[Levassor-Berrus 1920] André Levassor-Berrus, Loussert (Maurice-Marie-Joseph), né le 3 mars 1893, mort pour la France, le 25 septembre 1915, devant Saint-Souplet.-Promotion de 1913, Association amicale de secours des anciens élèves de l'École normale supérieure (Paris), 1920, p. $129-133$.

[Lhermitte 1917] Jules Lhermitte, Rousseau (Théophile), né à Bligny (Côte-d'Or) le 20 avril 1876, tué à l'ennemi à Avocourt, le 11 avril 1916. - Promotion de 1898, Association amicale de secours des anciens élèves de l'École normale supérieure (Paris), , 1917, p. 85-91.

[MacLeod 2000] Roy MacLeod, Sight and Sound on the Western Front: Surveyors, Scientists and the "Battlefield Laboratory," 1915-1918, War and Society 18 (2000), p. 23-46.

[MacLeod \& Andrews 1971] Roy MacLeod and E. Kay Andrews, Scientific Advice in the War at Sea 1915-1917: The Board of Invention and Research, Journal of Contemporary History 6 (1971), 3-40.

[MacLeod \& Johnson 2006] Roy MacLeod \& Jeffrey Johnson, eds., Frontline and Factory: Comparative Perspectives on the Chemical Industry at War, 1914-1924, Springer, Dordrecht, 2006.

[Marbo 1967] Camille Marbo [Marguerite Borel], A travers deux siècles, souvenirs et rencontres (1883-1967), Grasset, Paris, 1967.

[Mashaal 2006] Maurice Mashaal, Bourbaki: A Secret Society of Mathematicians, trans. Anna Pierrehumbert, American Mathematical Society, Providence, 2006.

[Mazliak \& Tazzioli 2009] Laurent Mazliak et Rossana Tazzioli, Mathematicians at War: Volterra and His French Colleagues in World War I, Springer, Berlin, 2009.

[Mehrtens 1990] Herbert Mehrtens, Moderne, Sprache, Mathematik: eine Geschichte des Streits um die Grundlagen der Disziplin und des Subjekts formeler Systeme, Surkamp, Frankfurt, 1990.

[Mehrtens 1996a] Herbert Mehrtens, Mathematics and War: Germany, 1900-1945, in National Military Establishmenst and the Advancement of Sciences: Studies in the 20th Century History, ed. P. Forman and J. M. Sánchez, Kluwer, Dordrecht, 1996, p. 87-134.

[Mehrtens 1996b] Herbert Mehrtens, Modernism vs. counter-modernism, nationalism vs internationalism: style and politics in mathematics 1900-1950, in textitL'Europe mathématique : mythes, histoires, identités, ed. C. Goldstein, J. Gray \& J. Ritter, Maison des Sciences de l'Homme, Paris, 1996, p. 517-529.

[Miller 1918] G. A. Miller, Scientific Activity and the War, Science 48 (1918), p. 117-118.

[Millikan 1919] Robert Millikan, A New Opportunity in Science, Science 50 (1919), 285-297.

[Morgan1918] Jeff H. A. Morgan, Relief Work among Civil and Military Prisoners in Siberia, The American Oxonian 5-6 (1918), 6-13.

[Moulton 1926] Forest Ray Moulton, New Methods in Exterior Ballistics, University of Chicago Press, Chicago, 1926.

[Moureu 1920] Charles Moureu, La Chimie et la guerre. Science et avenir, Masson, Paris, 1920.

[Mosse 1991] George L. Mosse, Fallen Soldiers: Reshaping the Memory of the World Wars, Oxford University Press, 1991

[Niriciand \& Becknstein 2007] Lawrence Niriciand and Edward Becknstein, The Hahn-Banach Theorem and the Sad Life of E. Helly, in Advanced Courses of Mathematical Analysis III: Proceedings of the Third International School, La Rabida, Spain, 3-7 September 2007, World Scientific, Singapore, 2008, p. 97-110.

[Noether 1919] Fritz Noether, Über analytische Berechnungen der Geschosspendelungen, Nachrichten von der Gesellschaft der Wissenschaften zu Göttingen, MathematischPhysikalische Klasse (1919), p 373-391. 
[Ollivier 1917] Héloïs Ollivier, Clairin (Jean), né à Nîmes le 13 novembre 1876, tué à l'ennemi à Thun-l'Évêque (Nord) le 26 août 1914. - Promotion de 1896, Association amicale de secours des anciens élèves de l'Ecole normale supérieure (Paris), Réunion générale annuelle (1917), p. 83-85.

[Olmsted 1974] John M. H. Olmsted, R. W. Brink: An Obituary, Amer. Math. Monthly 81(8) (1974), 873-875.

[Palazzo 1999] Albert P. Palazzo, The British Army's Counter-Battery Staff Office and Control of the Enemy in World War I, Journal of Military History 63 (1999), p. 55-74.

[Parshall \& Rowe 1994] Karen Hunger Parshall and David Rowe, The Emergence of the American Mathematical Research Community 1876-1900: J. J. Sylvester, Felix Klein, and E. H. Moore, AMS/LMS History of Mathematics 8, Providence/London, 1994.

[Parshall \& Rice 2002] Karen Hunger Parshall et Adrian C. Rice, Mathematics Unbound: The Evolution of an International Mathematical Research Community, 1800-1945, History of Mathematics 23, London Mathematical Society, London \& American Mathematical Society, Providence, 2002.

[Pasteur 1888] Louis Pasteur, Discours d'inauguration de l'Institut Pasteur, 14 novembre 1888, Annales de l'Institut Pasteur 2 suppl. (1888), p. 26-30.

[Pattison 1983] Michael Pattison, Scientists, Inventors, and the Military in Britain, 1915-19: The Munitions Inventions Department, Social Studies of Science 13 (1983), 521-568.

[Perrier 1915] Edmond Perrier, Allocution, CRAS 161 (1915), p. 801-819.

[Pier 1994] Jean-Pierre Pier, ed., Development of Mathematics, 1900-1950, Birkhäuser, Basel, 1994.

[Prandtl 1918] Ludwig Prandtl, Tragflügeltheorie. Nachrichten von der Gesellschaft der Wissenschaften zu Göttingen, Mathematisch-Physikalische Klasse (1918), p. 451-477; (1919), p. $107-137$.

[Prochasson \& Rasmussen 1996] Christophe Prochasson \& Anne Rasmussen, Au nom de la patrie: les intellectuels et la première guerre mondiale (1910-1919), La Découverte, Paris, 1996.

[Pourprix 2009] Marie-Thérèse Pourprix, Des mathématiciens à la Faculté des sciences de Lille, 1854-1971, L'Harmattan, Paris, 2009.

[Rachamimov 2002] Alon Rachamimov, POWs and the Great War: Captivity on the Eastern Front, Berg Publishers, New York, 2002.

[Rassias 1992] Themistocles M. Rassias, ed., The Problem of Plateau: A Tribute to Jesse Douglas and Tibor Radó, World Scientific, Singapore, 1992.

[Renteln 1997] Michael von Renteln, Paul Stäckel (1862-1919): Mathematiker und Mathematikhistoriker, in Überblicke Mathematik Vieweg, Braunschweig, 1997, p. 151-160.

[Riebesell 1916] PaulRiebesell, Mathematik im Krige, vol. I,1 of Deutsche Feld- und Heimatbücher, Teubner, Lepizig, 1916.

[Roussel 1989] Yves Roussel, Histoire d'une politique des inventions, 1887-1918, Cahiers pour l'histoire du CNRS 3 (1989), 19-57.

[Rowe 2004] David Rowe, Making Mathematics in an Oral Culture: Göttingen in the Era of Klein and Hilbert, Science in Context 17 (2004), 85-129.

[Runge 1915] Carl Runge, Mathematik und Bildung, Jahresbericht der Deutschen MathematikerVereinigung 24 (1915), p. 400-415.

[Russell 1988-1995] Bertrand Russell, Collected Papers, Unwin Hyman, London, 1988-1995.

[Sarton 1919] Georges Sarton, War and Civilization, Isis 2 (1919), p. 315-321.

[Saur \& Tribout de Morembert 1965-1966] Hubert Saur \& Henry Tribout de Morembert, Ferdinand Daussy, Mémoire de l'Académie nationale de Metz (1965-1966), p. 13-21.

[Schiavon 2003a] Martina Schiavon, Des savants-officiers entre science, armée, État et industrie de précision: les géodésiens du Service géographique de l'Armée, 1887-1920, in [Aubin \& Bret 2003, p. 60-73].

[Schiavon 2003b] Martina Schiavon, Itinéraires de la précision. Géodésiens, savants et fabricants d'instruments en France, 1870-1930 (environ), doctoral thesis, EHESS, Paris, 2003.

[Schmidt 1990] Marian Schmidt, Hommes de science, Hermann, Paris, 1990.

[Schroeder-Gudehus 1978] Brigitte Schroeder-Gudehus, Les Scientifiques et la paix : la communauté scientifique internationale au cours des années 20, Presses de l'université de Montréal, Montréal, 1978.

[Scott 1991] Joan Scott, Evidence of experience, Critical Inquiry 17 (1991), p. 773-797. 
[Seth 2010] Suman Seth, Crafting the Quantum: Arnold Sommerfeld and the Practice of Theory, 1890-1926, MIT Press, Cambridge, Mass., 2010.

[Siacci 1892] Francisco Siacci, Balistique extérieure, trans. P. Laurent, Berger-Levrault, Paris \& Nancy, 1892.

[Siegmund-Schultze 1984] Reinhard Siegmund-Schultze, Theodor Vahlen: zum Schuldanteil eines deutschen Mathematikers am faschistischen Mißbrauch der Wissenschaft, NTM Schriftenreihe zur Geschichte der Naturwissenschaften, Technik und Medizin 21 (1984), p. 17-41.

[Siegmund-Schultze 1994] Reinhard Siegmund-Schultze, "Scientific control" in mathematical reviewing and German-U.S.-American relations between the two World Wars, Historia Mathematica 21 (1994), p. 306-329.

[Siegmund-Schultze 2001] Reinhardt Siegmund-Schultze, Rockefeller and the Internationalization of Mathematics Between the Two World Wars, Birkhäuser, Basel \& Boston, 2001.

[Siegmund-Schultze 2003] Reinhard Siegmund-Schultze, Military Work in Mathematics 19141945: An Attempt at an International Perspective, in Mathematics and War, ed. Bernhelm Booß-Bavnbek \& Jens Høyrup, Birkhäuser, Basel, 2003, p. 23-82.

[Siegmund-Schultze 2004] Reinhard Siegmund-Schultze, A Non-Conformist Longing for Unity in the Fractures of Modernity: Towards a Scientific Biography of Richard von Mises (18831953), Science in Context 17 (2004), p. 333-370.

[Sigmund 2004] Karl Sigmund, Failing Phoenix: Tauber, Helly, and Viennese War Insurance, Mathematical Intelligencer 26 (2) (2004), 21-33.

[SMF 1924] Société mathématique de France, Vie de la société, Bulletin de la société mathématique de France (1924) p. 1-67.

[Smith 1914] David Eugene Smith, Problems about War for Classes in Arithmetic: Suggestions for Makers of Textbooks and for Use in Schools, Carnagie Endowment for Peace, 1914.

[Spitzmuller 1919] Georges Spitzmuller, Le Repérage par le son F. Rouff, Paris, 1919.

[Swerdlow 1993] Noel M. Swerdlow, Otto E. Neugebauer (26 May 1899-19 February 1990), Proceedings of the American Philosophical Society 137 (1993), p. 139-165.

[Szénássy 1992] Barna Szénássy, History of Mathematics in Hungary until the 20th Century, Springer, Berlin, 1992.

[Thiberge 1975] Thiberge, Le Service des Renseignements d'Artillerie Revue Historique des Armées de 2 (1975), p. 112-133.

[Tilho 1937] Jean Tilho, Notice sur la vie et les travaux de Gustave Ferrié (31 mai 1937), Académie des sciences, Notices et discours 2 (1949), p. 161-237.

[Tollmien 1993] Cordula Tollmien, Der "Krieg der Geister" in der Provinz: das Beispiel der Universität Göttingen 1914-1918, Göttinger Jahrbuch 41 (1993), p. 137-210.

[Tropp et al. 1993] Eduard A. Tropp, Viktor Ya. Frenkel, and Artur D. Chrnin, Alexander A. Friedmann: The Man Who Made the Universe Expand, trans. Alexander Dron and Michael Burov, Cambridge University Press, Cambridge, 1993.

[Trowbridge 1919] Augustus Trowbridge, Sound and Flash Ranging, Science 49 (1919), p. 521523.

[Vallier 1915] Emmanuel Vallier, Le tir indirect en 1915, Revue générale des sciences 16 (1916), p. $297-299$.

[Van der Kloot 2005] William Van der Kloot, Lawrence Bragg's Role in the Developement of Sound-Ranging in World War I, Notes and Records of the Royal Society 59 (2005), p. 273284.

[Varcoe 1970] Ian Varcoe, Scientists, Government and Organized Research in Great Britain 191416. The Early History of the DSIR, Minerva 8 (1970), p. 192-216.

[Vivanti 1916] Guilio Vivanti, Elementi della teoria delle equazioni integrali lineari, U. Hoepli, Milan, 1916.

[Weart 1979] Spencer Weart, Scientists in Power, Harvard University Press, Cambridge, Mass., 1979.

[Weil 1991] André Weil, Souvenirs d'apprentissage, Birkhäuser, Boston, 1991. English transl., The Apprenticeship of a Mathematician, Springer, New York, 1992.

[Weis 2005] Cédric Weis, Jeanne Alexandre: une pacifiste intégrale, Presses de l'université d'Angers, Angers, 2005.

[Wells 1915] H. G. Wells, Scientific War, Windsor Magazine 41 (1915), p. 237.

[Whitehead 1919] Alfred North Whitehead, An Inquiry concerning the Principles of Natural Knowledge, Cambridge Universuty Press, Cambridge, 1919. 
[Wieleitner 1915] Heinrich Wieleitner, Review of Carl Cranz's Lehrbuch der Ballistik, vols. 1, 3 and 4, in Jahrsbericht der Deutschen Mathematiker-Vereinigung 24 (1915), Sonstiges p. 5253.

[Wiener 1919] Otto Wiener, Die streckenweise Berechnung der Geschossflugbahnen, Abhandlungen der Sächsischen Akademie der Wissenschaften zu Leipzig, MathematischNaturwissenschaftliche Klasse 36, Teubner, Leipzig, 1919.

[Witkop 2002] Philipp Witkop, ed., German Students' War Letters, transl. Annie F. Wedd, University of Pennsylvania Press, Philadelphia, 2002.

[Witting 1916] Alexander Witting, Soldaten-Mathematik, Teubner, Leipzig, 1916.

[Wolff 2003] Stefan L. Wolff, Physicists in the "Krieg der Geister": Wilhelm Wien's "Proclamation", Historical Studies in the Physical and Biological Sciences 33 (2003), p. 337-368.

[Yerkes 1920] Robert M. Yerkes, The New World of Science: Its Development during the War, The Century Co., New York, 1920.

[Young 1981] Laurence Young, Mathematicians and Their Time, North Holland Publishing, Amsterdam, 1981.

Université Pierre et Marie Curie, Institut de mathématiques de Jussieu, 4 Place Jussieu, 75252 Paris Cedex 5, France

E-mail address: david.aubin@upmc.fr

CNRS, Institut de mathématiques de Jussieu, 4 place Jussieu, 75252 Paris Cedex 5, FRANCE

E-mail address: cgolds@math.jussieu.fr 